\title{
Batı Akdeniz Havzası Sınırlarının Yüksek Doğrulukla Belirlenmesi
}

\author{
Türkay GÖKGÖZ ${ }^{1}$ \\ Mustafa ERDOĞAN ${ }^{2}$ \\ Kemal SEYREK ${ }^{3}$ \\ i. Murat OZULU ${ }^{4}$
}

ÖZ

$\mathrm{Bu}$ çalışmada Batı Akdeniz Havzası sınırlarının yüksek doğrulukla belirlenmesi amaçlanmıştır. Bu amaç doğrultusunda 1:25,000 ölçekli yüksek doğruluklu 3 boyutlu vektör yükseklik ve hidrografya verileri kullanılarak coğrafi bilgi sistemleri araçlarıyla $10 \mathrm{~m}$ çözünürlüklü sayısal yükseklik modeli üretilmiş ve bu modelden havza sınırları türetilmiştir. Birinci düzey alt havzalardan biri Avlan Gölü'ne karşılık gelen çukur nesnesine dayalı olarak türetilen kapalı havzadır. Bu havza mevcut havza setlerinde bulunmamaktadır. Havza sınırlarının ve sayısal yükseklik modelinin doğruluğu sırasıyla ağırlıklı karesel ortalama yatay ve düşey konum hatalarına göre değerlendirilmiştir. Sonuç olarak, elde edilen havza sınırlarının ve sayısal yükseklik modelinin yüksek doğruluklu olduğu söylenebilir.

Anahtar Kelimeler: Batı Akdeniz Havzası, coğrafi bilgi sistemleri, sayısal yükseklik modelleri, karesel ortalama hata.

\section{ABSTRACT \\ Determining the High Accuracy Boundaries of Western Mediterranean Basin}

The purpose of this study is to determine the high accuracy boundaries of Western Mediterranean Basin. In accordance with this purpose, a digital elevation model with $10 \mathrm{~m}$ horizontal resolution is generated and the basin boundaries are derived from this model through the tools of geographical information systems using the high accuracy $3 \mathrm{D}$ vector

\footnotetext{
Not: Bu yazı

- Yayın Kurulu'na 25.04.2017 günü ulaşmıştır. 16.05.2018 günü yayımlanmak üzere kabul edilmiştir.

- 31 Temmuz 2019 gününe kadar tartışmaya açıktır.

- https://dx.doi.org/10.18400/tekderg.309105

1 Yıldız Teknik Üniversitesi, Harita Mühendisliği Bölümü, İstanbul - gokgoz@yildiz.edu.tr https://orcid.org/0000-0001-8716-6131

2 Harita Genel Komutanlığı, Fotogrametri Dairesi, Ankara - mustafa.erdogan@hgk.msb.gov.tr https://orcid.org/0000-0003-3219-5546

3 DSİ Genel Müdürlüğü, Teknoloji Dairesi Başkanlığı, Ankara - kseyrek@dsi.gov.tr https://orcid.org/0000-0002-4565-2438

4 Hitit Üniversitesi, Teknik Bilimler Meslek Yüksekokulu, Çorum - imuratozulu@hitit.edu.tr https://orcid.org/0000-0002-0963-3600
} 
elevation and hydrography data at 1:25,000 scale. One of the sub-basins at first level is a closed sub-basin, which is derived by using a sink in the model corresponding to Avlan Lake. It does not exist in the current basin sets. The accuracy of basin boundaries and digital elevation model are evaluated with respect to the weighted root mean square errors in position and height respectively. Consequently, it can be stated that basin boundaries and digital elevation model are obtained at high accuracy.

Keywords: Western Mediterranean Basin, geographical information systems, digital elevation models, root mean square error.

\section{GíRiș}

Günümüzde çözümlenmesi gereken en önemli problemlerden biri su kaynakları yönetimidir ve mevcut su kaynaklarından daha etkin yararlanılabilmesi ile çevresel problemlerin azaltılabilmesi bakımından bütünleşik havza yönetimi tüm dünyada önem kazanmaktadır. Bütünleşik havza yöntemini gerçekleştirebilmek için öncelikle havza sınırlarının yeterli doğruluk ve duyarlıkta belirlenmesine ihtiyaç duyulmaktadır. Havza sınırları büyük oranda coğrafi bilgi sistemlerinde (CBS) sayısal yükseklik modellerinden (SYM) türetilmektedir. Veri kaynağına ve kullanım amacına bağlı olarak SYM üretiminde kullanılabilecek çeşitli enterpolasyon (ara hesaplama) yöntemleri (2. ve 3. derece polinomlar (çok terimliler) ile enterpolasyon, multiquatrik (çoklu ikinci dereceliler) enterpolasyon, ağırlıklı aritmetik ortalama ile enterpolasyon, kayan yüzey yardımıyla enterpolasyon, yüzey toplamları ile enterpolasyon, sürekli parça parça polinomlar ile enterpolasyon, dörtgen gridde (ağda) enterpolasyon, üçgen ağında enterpolasyon, vd.) vardır [1]. Günümüzde jeomorfometrik analizler için SYM'lerin üretiminde en yaygın kullanılan ve literatürde önerilen yöntemlerden biri Hutchinson [2] tarafından "ayrıklaştırılmış ince plaka spline tekniğine" dayalı olarak geliştirilmiş enterpolasyon yöntemidir [3]. Bu yöntemde ilave yüksseklik ve hidrografya verileri de kullanılarak -aşağıda bahsedilen- yapay çukurlar ortadan kaldırılırken drenaj çizgilerine denk gelen SYM noktalarının kotları dengelenmektedir. Bu nedenle, bu yöntemle elde edilen SYM "hidrolojik düzeltilmiş SYM" olarak adlandırılmaktadır. Böylece, sürekli formda drenaj ağları türetmek mümkün olmaktadır. Aynı zamanda kartografyadaki "arazinin iskelet çizgileri (bu çalışmadaki karşılığı drenaj ağı) münhanilerin maksimum eğriliğe sahip noktalarında konumlanmalıdır [4,5]” koşulu da sağlanmaktadır.

Bir sayısal yükseklik modelinden havza sınırları başlıca aşağıdaki işlem adımlarıyla belirlenmektedir [6,7]:

- Çukurların doldurulması,

- Akış doğrultularının belirlenmesi,

- Akış birikinti değerlerinin hesaplanması ve

- Akış birikinti değerlerine göre drenaj ağlarının türetilmesi ve havza sınırlarının belirlenmesi.

Veri toplama tekniğine ve çözünürlüğe bağlı olarak genellikle SYM'lerde yapay çukurlar ortaya çıkar. Bunlar drenaj ağında kopukluklar meydana gelmesine, başka bir deyişle sürekli 
bir drenaj ağı elde edilememesine neden olur. Ayrıca yine aynı nedenlerle drenaj ağında yatay konum hataları meydana gelir. O'Callaghan ve Mark [8] ve Mark [9] tarafindan bu çukurlar yumuşatma yoluyla ortadan kaldırılmaya çalışılmıştır. Sığ çukurlarda başarılı olan bu yaklaşım, derin çukurlarda başarılı olamamaktadır. Bir diğer yaklaşım ise çukur içinde kalan her bir noktanın çukur sınırı boyunca en düşük kotlu nokta seviyesine getirilmesi yoluyla çukurun doldurulmasıdır [10].

Akış doğrultularını belirlemek için en yaygın olarak kullanılan yaklaşım ilk olarak O'Callaghan ve Mark [8] ve Mark [9] tarafindan tanitılan ve kısaca D8 olarak bilinen "belirleyici sekiz nokta" yaklaşımıdır. Çukurlara ve düzlüklere duyarlı oluşu, basit ve etkili hesaplama tekniği nedeniyle günümüzde ticari yazılımların hemen tamamı bu yaklaşımı kullanmaktadır [11]. Bununla birlikte, "rastgele dört/sekiz nokta", "çoklu akış doğrultusu" ve kısaca Do olarak bilinen çeşitli yaklaşımlar da vardır [11-13].

Çukurların doldurulması "yapay düzlükler" ve beraberinde "yapay drenaj çizgileri" sorununu getirmektedir. $\mathrm{Bu}$ sorunla yalnız yapay düzlüklerde değil, aynı zamanda sabit eğimli yamaçlarda da karş̧laşılmaktadır [10]. Bu sorunu aşmak için bir dizi araştırma yapılmıştır [14-21]. Bu sorun, Gülgen ve Gökgöz [22] tarafından geliştirilen, klasik D8 yaklaşımı ile PPA (Profile Recognition and Polygon Breaking Algorithm) algoritmasının matematik temellerinin birleştirildiği yaklaşımla tam olarak aşılmıştır.

Havza sınıları, akış birikinti değerlerinden türetilen drenaj ağlarına göre belirlenmektedir. Drenaj ağlarının türetilmesinde belirleyici olan akış birikinti eşik değeridir. Farklı akış birikinti eşik değerleri, uzunluk ve çizgi nesne sayısı bakımından farklı drenaj ağlarının türetilmesi ve dolayısıyla sayı ve alan bakımından farklı havzaların belirlenmesi sonucunu doğurmaktadır [6,13]. Bu bağlamda, drenaj ağlarının türetilmesi ve havza sınırlarının belirlenmesinde en kritik aşamalardan biri akış birikinti eşik değerinin belirlenmesidir.

Akış birikinti eşik değerinin belirlenmesinde iyi bilinen üç temel yaklaşım vardır. Birincisi, yaygın olarak kullanılan CBS araçlarının da kullanıcıya hazır olarak sunduğu, maksimum akış birikinti değerinin \% 1'inin akış birikinti eşik değeri olarak kullanılmasıdır [23]. Bir diğer yaklaşım, ortalama akış birikinti değerinin kullanılmasıdır [24]. Üçüncü olarak, mevcut akarsuları temsil eden çizgi nesnelerin membalarında hesaplanan akış birikinti değerlerinin ortalamasının eşik değer olarak kullanılmasıdır [25]. Gökgöz vd. [13] tarafından geliştirilen dördüncü yaklaşımda ise türetilecek drenaj ağındaki çizgilerin uç noktalarını içeren hücreler arasındaki yakınlık ve doğrultu ilişkisi dikkate alınarak akış birikinti eşik değeri belirlenmektedir.

Avrupa Birliği ile müzakere süreci devam eden Türkiye, Avrupa Birliği Direktifleri doğrultusunda yükümlülüklerini yerine getirmeye çalışmaktadır. Bu çalışmanın konusunu doğrudan ilgilendiren iki Avrupa Birliği Direktifi vardır: WFD (Water Framework Directive) ve INSPIRE (Infrastructure for Spatial Information in Europe). 23 Ekim 2000 tarihinde yürürlüğe giren WFD [26] hedefleri; tüm kıta içi yüzey ve yer altı suları ile kıyı ve geçiş sularını, su ekosistemlerini ve suya bağlı karasal ekosistemlerini korumak, bozulmalarını ve kirlenmelerini önlemek, taşkınların ve kuraklığın etkilerinin yumuşatılmasına katkıda bulunmak ve su kaynaklarının korunmasını sağlamaktır. Direktif, hedeflerine ulaşmak için havza bazında yönetim esasını benimsemiştir [27]. 2019 yılında tamamlanacak bir süreçte farklı uygulama aşamalarını içeren INSPIRE direktifi 15 Mayıs 2007 tarihinde yürürlüğe girmiştir. INSPIRE direktifi, Avrupa Parlamentosu mekânsal veri altyapısını oluşturmayı 
amaçlamaktadır. Bu durum Avrupa içinde çevreyle ilgili mekânsal verilerin kamu kurumları arasında paylaşılmasına ve mekânsal bilgilere kamusal erişimin daha kolay hale gelmesine olanak tanıyacaktır. INSPIRE, sınırları aşan bir politikanın oluşturulmasına yardımcı olacaktır. Bu yüzden direktifin kapsadığı mekânsal veri yaygın olup, çok çeşitli başlık ve teknik temaları kapsamaktadır. Bunlardan biri de hidrografya temasıdır. Drenaj ağı ve havza nesneleri bu tema kapsamındadır. Hidrografya temasındaki tüm nesneler WFD'ye uygun olarak tanımlanmıştır. INSPIRE Hidrografya Çalışma Grubu tarafından hazırlanan ve 26.04.2010 tarihinde yayınlanan yönergede hidrografya teması tüm ayrıntıları ile açıklanmaktadır. Türkiye'de INSPIRE'a uygun hidrografya veri seti henüz mevcut değildir. Bununla birlikte, Haziran 2017 tarihine kadar kullanıma hazır hale getirilmesi planlanmıştır [28,29]. Bugüne kadar çeşitli çalışmalar yapılmış ve çeşitli veri tabanları üretilmiş olmasına karşın, Avrupa düzeyinde de INSPIRE'a tamamen uygun bir hidrografya veri seti henüz mevcut değildir.

Bu çalışmada, Avrupa Birliği direktifleri perspektifiyle ve özgün bir metodolojiyle Batı Akdeniz Havzası sınırlarının yüksek doğrulukla belirlenmesi amaçlanmıştır. Doğruluk değerlendirmesi için havza sınırlarının ağırlıklı karesel ortalama yatay konum hatası ve sayısal yükseklik modelinin ağırlıklı karesel ortalama düşey konum hatası hesaplanmıştır. Bölüm 2'de ayrıntılı olarak açıklanan metodolojiye göre elde edilen sonuçlar Bölüm 3'te verilmiştir. Sonuçlara dayalı değerlendirmeler ise Bölüm 4'te bulunmaktadır.

\section{METODOLOJI}

Bu çalışmada, her biri ayrı bir başlık altında ayrıntılı açıklanan aşağıdaki adımlar izlenmiştir.

- Verilerin yeniden konumlandırılması

- Veri temizleme ve düzenleme

- Temizlenmiş verilerin kaynaştırılarak tek bir veri tabanında toplanması

- Kıyı çizgisinin sıfır kotlu münhani olarak bütünleşik veri tabanına dâhil edilmesi

- Pafta bazında SYM sinırlarının belirlenmesi

- Pafta bazında SYM üretiminde kullanılacak verilerin bütünleşik veri tabanındaki verilerden kırpılarak elde edilmesi

- SYM'lerin üretilmesi

- Hidrolojik ağın elde edilmesi

- Hidrolojik analiz 1: Kapalı havza sınırı ve drenaj çizgilerinin türetilmesi

- Hidrolojik analiz 2: Havza ve alt havza sınırlarının türetilmesi

- Havza sinırı karesel ortalama yatay konum hatasının hesaplanması

- SYM karesel ortalama düşey konum (yükseklik) hatasının hesaplanması

\subsection{Verilerin Yeniden Konumlandırılması}

$\mathrm{Bu}$ çalışmada, Harita Genel Komutanlığınca (HGK) üretimi yapılan TOPO25 veri tabanlarındaki yükseklik (münhani ve kot noktası) ve hidrografya (geniş dere, dar dere, kanal, 
göl ve kıyı) verileri kullanılmıştır. Bu veriler 3 boyutlu nokta ve çizgi geometri tipinde vektör verilerdir. Bu verilerin üretiminde 2009 ve 2010 tarihli hava fotoğrafları kullanılmıştır. Hava fotoğrafları $6000 \mathrm{~m}$ yükseklikten yaklaşık 1:65,000 ölçeğinde çekilmiş olup, $45 \mathrm{~cm}$ çözünürlüğe sahiptir. Bu fotoğrafların yöneltilmesinde GPS/IMU bilgileri ve yaklaşık 1:100,000 ölçekli paftayı kapsayan bir blokta jeodezik yöntemle ölçülmüş ve işaretlenmiş en az 4 yer kontrol noktası kullanılmıştır. Fotogrametrik nirengi ve dengeleme işlemleri MatchAT yazılımında 44 parametreli self-kalibrasyon ile yapılmıştır. Dengeleme sonucu tüm noktalarda elde edilen iç doğruluklar yatayda $\pm 5 \mathrm{~cm}$, düşeyde $\pm 15 \mathrm{~cm}$, yer kontrol noktaları karesel ortalama hataları ise yatayda $\pm 50 \mathrm{~cm}$, düşeyde $\pm 1 \mathrm{~m}$ civarındadır. Bu nedenle veriler yüksek doğruluğa sahiptir. Ana münhani aralığg (eş yükseklik değeri) $10 \mathrm{~m}$ ve düşey konum (yükseklik) doğruluğu \%95 güven düzeyinde $\pm 3 \mathrm{~m}$ 'dir. Hidrografya verilerinin yatay (planimetrik) ve düşey (yükseklik) konum doğruluğu \% 95 güven düzeyinde sırasıyla $\pm 4 \mathrm{~m}$ ve \pm 3 m'dir. Batı Akdeniz Havzasına ait veriler 207 adet veri tabanında yer almaktadır.

Özgün veriler coğrafi koordinat sisteminde konumlandırılmıştır. Coğrafi koordinat sisteminde konumlandırılmış verilerle de analizler yapılabilir. Ancak, bu sistemde ekvatordan uzaklaştıkça deformasyon miktarı giderek artar ve bu durum analiz sonuçlarını olumsuz etkiler. Bu nedenle, koordinat sisteminden kaynaklı hataları minimize etmek için özgün verilerin uygun bir projeksiyonda yeniden konumlandırılması yoluna gidilmiştir. Uygun projeksiyon, amaca (verilerin hangi amaç doğrultusunda ne tür analizlerde kullanılacağına), çalışma bölgesinin konumuna (ekvator bölgesinde, kutup bölgesinde, vb.), biçimine (doğu-batı uzanımlı, kuzey-güney uzanımlı, vb.) ve büyüklüğüne bağlı olarak belirlenir.

Batı Akdeniz Havzası orta enlem kuşağında (36.13 ve 37.67 derece enlemleri arasında) doğubatı uzanımlı (27.23 ve 30.59 derece boylamları arasında) oldukça büyük (yaklaşık 20,332 $\mathrm{km}^{2}$ ) bir havzadır. Hidrolojik analizler açı (şekil) bilgisinden çok uzunluk ve alan bilgisinin önemli olduğu analizlerdir. $\mathrm{Bu}$ nedenlerle bu çalışmada Albers alan koruyan konik projeksiyon tercih edilmiştir.

$\mathrm{Bu}$ çalışmanın sürdürülebilir olması (bu çalışmada geliştirilen yaklaşımla ülkemizin diğer havzaları için de benzer çalışmaların yapılabilir olması) için Albers alan koruyan konik projeksiyonun parametrelerinin havza bazında değil ülke bazında belirlenmesi gerektiği düşüncesiyle, HGK tarafından bu projeksiyon için ülkemizin bütünü göz önüne alınarak belirlenen aşağıdaki parametreler aynen kullanılmıştır.

$\begin{array}{ll}\text { Projeksiyon } & : \text { Albers } \\ \text { Sağa Değer (Başlangıç) } & : 0 \\ \text { Yukarı Değer (Başlangıç) } & : 0 \\ \text { Orta Meridyen } & : 35 \\ \text { Standard Paralel 1 } & : 36.5 \\ \text { Standard Paralel 2 } & : 41 \\ \text { Başlangıç Enlemi } & : 0 \\ \text { Uzunluk Birimi } & : \text { Metre } \\ \text { Coğrafi Koordinat Sistemi } & : \text { WGS_1984 } \\ \text { Datum } & : \text { WGS_1984 }\end{array}$


$\begin{array}{ll}\text { Başlangıç Meridyeni } & \text { : Greenwich } \\ \text { Açı Birimi } & \text { : Derece }\end{array}$

\subsection{Veri Temizleme ve Düzenleme}

$\mathrm{Bu}$ aşamada verilerin hatalardan arındırılması hedeflenmiştir. Olası hatalar şunlardır: Yükseklik değeri yanlış olan kot noktası, yükseklik değeri $0 \mathrm{~m}$ olan münhani, yükseklik değeri yanlış olan münhani, çok parçalı tek nesne biçiminde meydana getirilmiş dar dere, akış yönünün tersi yönünde çizilmiş dere, kesişen münhani, iki kez çizilmiş münhani, derinlik eşdeğer çizgisi niteliğinde çizilmiş münhani, münhaniyle kesişen göl, bir noktada birleşen iki kolun tek bir nesne olarak meydana getirildiği nesne, bir noktada birleşen iki kolun münferit tek bir nesne olarak meydana getirildiği nesne, eyer biçimli boyun şeklindeki arazilerde boyunun iki tarafındaki derelerin boyundan itibaren alçalan iki çizgi ile değil boyunu da geçen tek bir çizgi ile meydana getirildiği dere, çizilmemiş/eksik kanal, vd. Hatalı nesnelerin tespitinde ve düzenlenmesinde hem manuel, hem hazır araçlar (ArcGIS'in Topology, Data Reviewer ve Editing araçları), hem de AutoCAD'in makro programlama dili olan AutoLISP ile yazılan bir program (tersdere.lsp) kullanılmıştır. Tersdere programının algoritması kısaca şöyledir: Bir çizgi ele alınır. Çizginin başlangıç ve son noktası arasındaki yükseklik farkı hesaplanır. Yükseklik farkının sıfırdan küçük olması durumunda, ele alınan geniş dere/dar dere/kanal akış yönünün tersi yönünde çizilmiş demektir ve çizgi son noktasından başlangıç noktasına doğru birleştirilerek yeniden meydana getirilir. Böylece, ele alınan geniş dere/dar dere/kanal akış yönü düzeltilmiş olur. Bu şekilde tüm çizgiler sırayla ele alınır.

Nesne ilişkilerine dayalı olarak hataları tespit etmek için topoloji oluşturulmuştur. Böylece; kendisiyle örtüşen, kendisiyle kesişen, aynı sınıfta veya başka bir sınıfta bir nesneyle örtüşen, aynı sınıfta veya başka bir sınıfta bir nesneyle kesişen, başka bir nesneye o nesnenin son noktası dışında bir noktasında birleşen ya da kesen, bir bütün olması gerekirken ardışık iki ya da daha fazla nesne olarak meydana getirilen hatalı nesneler tespit edilmiş ve çeşitli araçlarla düzeltilmiş ya da silinmiştir.

Yukarıdaki aşamalardan geçen veriler son olarak ArcGIS Data Reviewer aracı ile kalite kontrol işlemlerine tabi tutulmuş ve verilerin yapılacak analizlerde kullanılabilir nitelikte olduğu anlaşılmıştır.

\subsection{Temizlenmiş Verilerin Kaynaştırılarak Tek Bir Veri Tabanında Toplanması}

207 adet veri tabanındaki temizlenmiş veriler nesne sınıflarına göre kaynaştırılarak altı katmanlı yeni bir bütünleşik veri tabanı oluşturulmuştur.

\subsection{Kıyı Çizgisinin Sıfır Kotlu Münhani Olarak Bütünleşik Veri Tabanına Dâhil Edilmesi}

Özgün veri tabanlarında sıfır kotlu münhaniler bulunmamakla birlikte kıyı nesneleri vardır. Ancak, kıyı nesneleri sabit (her noktasında) $0 \mathrm{~m}$ kotlu çizgiler değil, nokta yükseklikleri $1.05 \mathrm{~m}$ ile $22.36 \mathrm{~m}$ arasında değişen çizgilerdir. Bu nedenle, özgün veri tabanlarındaki kıyı 
nesneleri birleştirilmiş, sabit $0 \mathrm{~m}$ kotlu birer çizgi olacak şekilde yeniden düzenlenmiş ve bütünleşik veri tabanındaki münhani katmanına ilave edilmiştir.

\subsection{Pafta Bazında SYM Sınırlarının Belirlenmesi}

207 adet veri tabanındaki verilerin tümünü birden kullanarak ArcGIS TopoToRaster aracı ile bir SYM elde edilmesi mümkün olmamıştır. Verinin hacmi TopoToRaster aracının işlem kapasitesinin çok üstündedir. Bu nedenle TopoToRaster aracı ile pafta/veri tabanı bazında SYM'ler üretilmesine, üretilen SYM'lerin ArcGIS Mosaic aracı ile bir araya getirilmesine ve böylece Batı Akdeniz havzasının bütünleşik SYM'sinin elde edilmesine karar verilmiştir. Ancak, pafta bazında SYM'ler üretildiğinde ve bu SYM'ler bir araya getirildiğinde kenarlaşma problemi; başka bir deyişle, SYM sınırları boyunca yükseklik hataları ortaya çıkar. Çünkü TopoToRaster aracının yaptığı işlem özde bir enterpolasyon işlemidir: Girdi olarak verilen topoğrafya ve hidrografya verilerinden enterpolasyon yoluyla SYM hücrelerinin yükseklik değerleri hesaplanır. Enterpolasyon işleminin etkisi sınırlara doğru giderek artar. Bu nedenle, bindirmeli SYM'lerin yani, sınırları boyunca ortak alanları olan SYM'lerin bir araya getirilmesi en iyi yoldur. Ortak alanlar, özgün pafta sınırları belli bir miktar genişletilerek meydana getirilebilir. Fakat bu kez yeni sınırlar boyunca kenarlaşma problemi ortaya çıkar. Kenarlaşma problemini bütünüyle ortadan kaldırmak için bu çalışmada şöyle bir yol izlenmiştir: (1) Özgün pafta sınırı 6000 m genişletilerek yeni bir sınır meydana getirilmiş, (2) bu yeni sınır içinde kalan verilerle bir SYM üretilmiş, (3) özgün pafta sınırı $3000 \mathrm{~m}$ genişletilerek yeni bir sınır daha meydana getirilmiş ve (4) ikinci adımda üretilen SYM, üçüncü adımda meydana getirilen sınıra göre kırpılmıştır. $3000 \mathrm{~m}$ ve $6000 \mathrm{~m}$ mesafeleri yapılan bir dizi test sonucunda belirlenmiştir.

\subsection{Pafta Bazında SYM Üretiminde Kullanılacak Verilerin Bütünleșik Veri Tabanındaki Verilerden Kırpılarak Elde Edilmesi}

Özgün pafta sınırları 6000 m genişletilerek elde edilen SYM sınırlarına göre bütünleşik veri tabanındaki münhani, kot noktası, geniş dere, dar dere ve göl verileri kırpılmış ve böylece pafta bazında SYM üretiminde kullanılacak veriler elde edilmiştir.

\subsection{SYM'lerin Üretilmesi}

Hengl [30], uygun SYM çözünürlüğünün belirlenmesi konusunu ele aldığı yazısında, Weihau ve Montgomery [31] tarafindan 2, 4, 10, 30 ve 90 m çözünürlüklü SYM ile gerçekleştirilen bir çalışmada en uygun sonuçların $10 \mathrm{~m}$ çözünürlüklü SYM ile elde edildiğini ifade etmektedir. Kendisi tarafindan gerçekleştirilen bir çalışmaya dayalı olarak da $10 \mathrm{~m}$ aralıklı münhanilerden üretilecek SYM için en uygun çözünürlüğün 12.0-53.5 m aralığında olabileceğini belirtmektedir. Ayrıca, çalışma ölçeğine bağlı olarak en düşük, en yüksek ve makul SYM çözünürlüğünün hesabında kullanılabilecek bağıntıları vermektedir. Buna göre, SYM çözünürlüğ̈̈; $S N \times 0.0025$ bağıntısı ile hesaplanacak değerden daha düşük ve $S N \times$ 0.0001 bağıntısı ile hesaplanacak değerden daha yüksek olmamalıdır. Makul değer ise $S N \times$ 0.0005 bağıntısı ile hesaplanabilir. Bu bağıntılarda geçen $S N$, ölçek faktörü ya da sayısıdır. $\mathrm{Bu}$ çalışmada kullanılan münhaniler 1:25,000 ölçekli veri setinde yer almaktadır. Bu 
bağlamda, $S N=25,000$ alınarak hesap yapıldığında en düşük, en yüksek ve makul çözünürlük için sırasıyla 62.5, 2.5 ve 12.5 m değerleri elde edilmektedir. Ayrıca, Erdoğan [32] tarafından yapılan çalışmada, 2008 yılına kadar 1:25,000 ölçekli topoğrafik haritaların üretiminde kullanılan 1:35,000 ölçekli hava fotoğraflarından $10 \mathrm{~m}$ aralıklı münhani üretimi ve otomatik görüntü eşleme ile elde edilecek SYM'lerin en iyi (optimum) çözünürlüğünün 8-16 m arasında olması gerektiği ifade edilmektedir. Bu bilgiler ışı̆̆ında bu çalışmada üretilecek SYM için çözünürlük değeri $10 \mathrm{~m}$ olarak belirlenmiştir.

Bütünleşik SYM'nin elde edilmesi için öncelikle pafta bazında SYM üretimi için hazırlanan veriler kullanılarak ArcGIS TopoToRaster aracı ile 207 adet SYM üretilmiştir. 207 adet SYM'in her biri ArcGIS Extract by Mask aracı ile kırpılarak bütünleşik SYM üretiminde kullanılacak SYM'ler elde edilmiştir. Bu SYM'ler ArcGIS Mosaic aracı ile birleştirilerek de bütünleşik SYM elde edilmiştir.

\subsection{Hidrolojik Ağın Elde Edilmesi}

Hidrolojik ağın elde edilmesine ilişkin akış diyagramı Şekil 1'de görünmektedir. Öncelikle bütünleşik geniş dere katmanında yer alan nesnelerin tümü ve bütünleşik dar dere katmanında yer alan kalıc1/sürekli dere niteliğindeki nesnelerin tümü seçilmiş ancak sürekli formda bir ağ elde edilememiştir. Aralardaki boşlukların çoğunda bütünleşik dar dere katmanında yer alan kuru dere niteliğindeki nesnelerin bulunduğu görülmüştür. Bununla birlikte, bazı boşluklar ardışık bir-iki kuru dere ile tamamlanabilecekken, bazılarının tamamlanabilmesi için ardışık çok sayıda kuru derenin seçilmesi gerektiği; başka bir deyişle, bazı geniş ve kalıc1/sürekli derelerin birbirlerinden çok uzak konumlarda bulunduğu tespit edilmiştir. Çok az sayıdaki böylesi geniş ve kalıcı/sürekli dereler elimine edilmiştir. Geriye kalan çok az boşlukta ise bütünleşik kanal katmanında yer alan çoğu geniş kanal niteliğindeki nesnelerin bulunduğu görülmüştür. Kısacası, geniş dere ve kalıc1/sürekli derelerin hemen tamamı, kuru dere ve kanallardan ise boşlukları dolduracak olanlar seçilerek büyük ölçüde sürekli formda bir ağ elde edilmiştir. Anlaşılacağı üzere ağın doğal nesnelerden meydana gelmesine özen gösterilmiştir. Elde edilen ağın nesne sayısı bakımından yalnızca yaklaşı \% 1'i yapay nesnelerden (kanallardan) meydana gelmiştir. İkinci aşamada bu ağdaki nesneler ile ilişki içinde olan göller seçilmiştir. Seçilen göllerin ArcGIS Polygon to Centerline aracı ile 2B orta eksenleri türetilmiştir. 2B orta eksenleri 3B orta eksenlere dönüştürmek (orta eksen noktalarına yükseklik değeri atamak) için ArcGIS Create TIN aracı ile 3B poligonlar kullanılarak düzensiz üçgen ağı (Triangulated Irregular Network - TIN) modelleri meydana getirilmiştir. ArcGIS Interpolate Shape aracı ile bu modellerde orta eksen noktalarının yükseklikleri hesaplanmış ve $z$ değerleri olarak atanmıştır. Böylece 2B orta eksenler 3B orta eksenlere dönüştürülmüştür. Üçüncü aşamada, seçilen göllerin $3 \mathrm{~B}$ orta eksenlerine erişememiş olan kollar uzatılarak aralardaki boşluklar doldurulmuş ve böylece süreklilik sağlanmıştır. Böylece ortaya çıkan ağın kolları ayrıntılı incelendiğinde bazı kollarda -deyim yerindeyse- kasisler olduğu görülmüştür. Başka bir deyişle, bazı kollarda başlangıç noktalarından son noktalarına kadar sürekli alçalma olmadığı, desimetre mertebesine kadar yükselmelerin olduğu tespit edilmiştir. Akarsuların doğasına aykırı olan bu durumları ortadan kaldırmak için AutoCAD'in makro programlama dili olan AutoLISP ile bir program (kasislidere.lsp) yazılmıştır. 
Türkay GÖKGÖZ, Mustafa ERDOĞAN, Kemal SEYREK, I. Murat OZULU

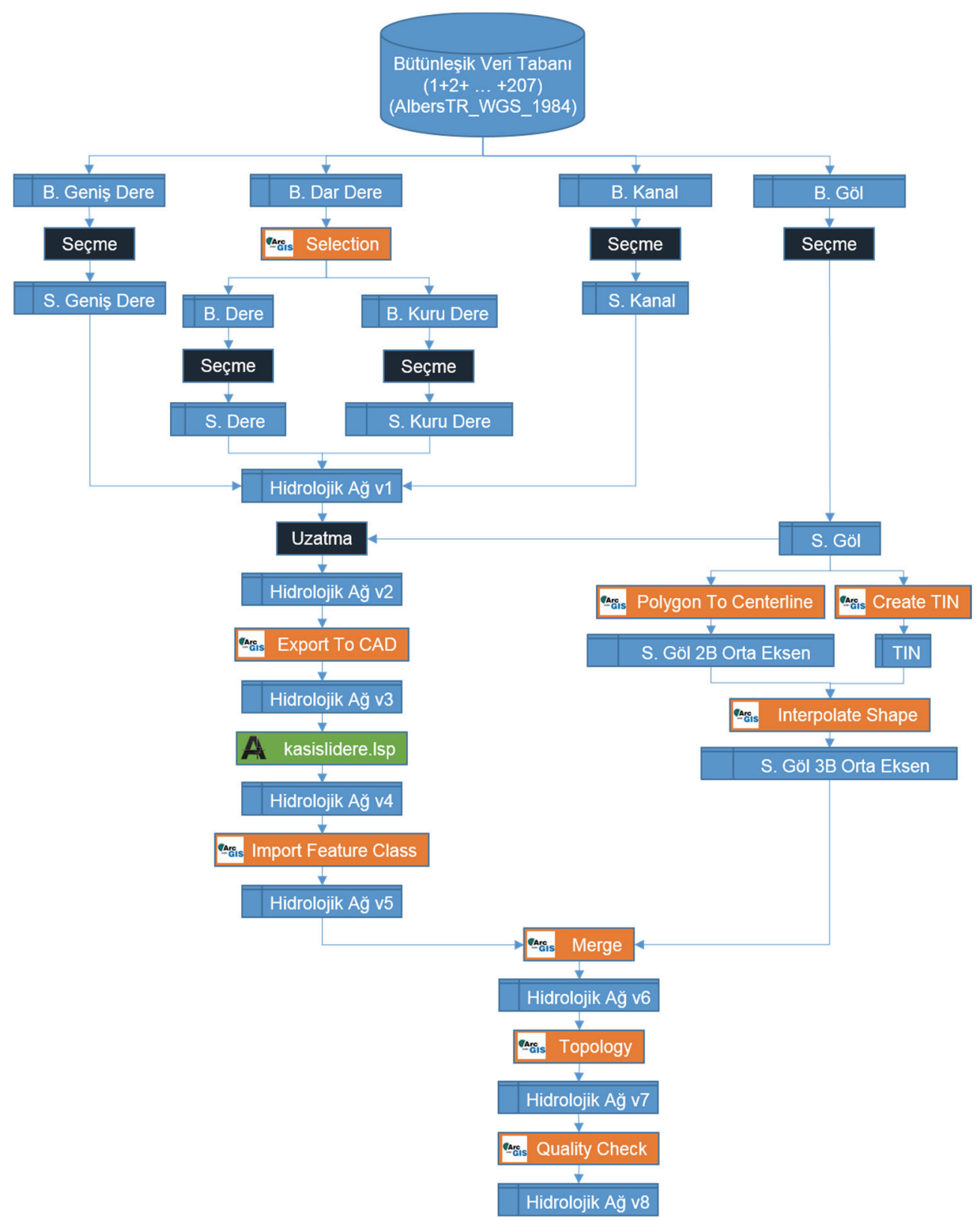

Şekil 1 - Hidrolojik ağın elde edilmesi (Kısaltmalar: Bütünleşik (B.), Seçilen (S.), Versiyon (v); Renkler: Turuncu (ArcGIS Araçları), Yeşil (AutoLISP Programı), Lacivert (Manuel), Mavi (Girdiler ve Çıktılar)) 
Kasislidere programı ile hidrolojik ağın her kolu sırayla ele alınarak kolları meydana getiren noktaların yükseklik değerleri incelenmektedir. Bir noktanın yükseklik değeri bir önceki noktanın yükseklik değerinden küçük ise o nokta seçilmekte, tersi durumda elenmektedir. Son olarak, bir kolun başlangıç noktası, son noktası ve seçilen noktalarıyla yeni bir çizgi meydana getirilmektedir. Kasis problemi de giderildikten sonra tüm çizgiler (tüm kollar ve 3B göl orta eksenleri) kaynaştırılmıştır. Son aşamada, hidrolojik ağın son haliyle topoloji oluşturulmuş ve kendisiyle örtüşen, kendisiyle kesişen, başka bir çizgiyle örtüşen, başka bir çizgiyle kesişen, başka bir çizgiyle o çizginin son noktası dışında bir noktasında birleşen ya da kesen, bir bütün olması gerekirken ardışık iki ya da daha fazla çizgi olarak meydana getirilen hatalı çizgiler tespit edilmiş ve çeşitli araçlarla düzeltilmiştir. Son olarak ArcGIS Data Reviewer aracı ile kalite kontrol işlemlerine tabi tutulmuş ve hidrolojik ağın artık ArcHydro Create Drainage Line Structures işleminde kullanılmaya hazır olduğu anlaşılmıştır.

Bölgede sürekli formda bir hidrolojik ağ elde edilememesinin başlıca nedenlerinden biri Avlan Gölü yakınında bulunan "eyer biçimli boyun" şeklindeki arazidir. Bu boyun, kuzeyindeki derelerin denize ulaşmasına engel olmaktadır. Başka bir deyişle, bu bölgede suların Avlan Gölü'nde toplandığı bir kapalı havza vardır. Bu nedenle hidrolojik ağın bu kısmında (boyun bölgesinde) bir kopukluk meydana gelmektedir. Bu aşamada görsel incelemelerle tespit edilmiş olan bu kapalı havza, bir sonraki aşamada ArcGIS ArcHydro araçları yardımıyla otomatik olarak türetilmiştir.

\subsection{Hidrolojik Analiz 1: Kapalı Havza Sınırı ve Drenaj Çizgilerinin Türetilmesi}

Şekil 2'deki akış diyagramında göründüğü gibi kapalı havza sınırı, bütünleşik SYM'de Avlan Gölü'ne karşılık gelen çukura (sink) dayalı olarak türetilmiştir. Çukurlar ise ArcHydro Sink Evaluation aracıyla belirlenmiştir.

Drenaj çizgileri, ArcHydro Stream Definition aracının 'Number of cells to define stream' parametresine Gökgöz vd. [13] tarafından geliştirilen ve kısaca BeST (Best Stream Threshold) adıyla anılan yaklaşıma göre belirlenen değer girilerek elde edilen 'stream grid'e dayalı olarak türetilmiştir. BeST yaklaşımına göre birikinti eşik değeri c\# programlama dilinde yazılan bir program ile hesaplanmıştır. Tam otomatik çalışan BeST programının girdileri; akış doğrultu (flow direction) ve akış birikinti (flow accumulation) dosyalarıdır. Raster veri yapısındaki bu dosyalar birer matris gibi düşünülebilir. BeST algoritmasına göre akış birikinti eşik değerine bağlı olarak akış birikinti matrisinden drenaj matrisi (stream definition) elde edilmekte ve bu matrise göre akış doğrultuları incelenerek çizgilerin başlangıç noktalarında paralellik olup olmadığı tespit edilmektedir. Akış birikinti eşik değeri için başlangıç değeri 1'dir. Paralellik tespit edilmesi durumunda akış birikinti eşik değeri bir artırılarak aynı işlemler yeniden gerçekleştirilmektedir. Paralelliğin tespit edilmediği durumda kullanılan akış birikinti eşik değeri BeST değeri olarak kabul edilmektedir. BeST değeri, türetilecek drenaj ağında komşu iki hücreden başlayan çizgiler olmamasını garanti etmektedir. Bununla birlikte, komşu iki hücreden başlamayan iki çizgi giderek birbirine yaklaşabilir, belli bir yerden sonra komşu olabilir, paralel yol alabilir ve bir noktada birleşebilirler. 


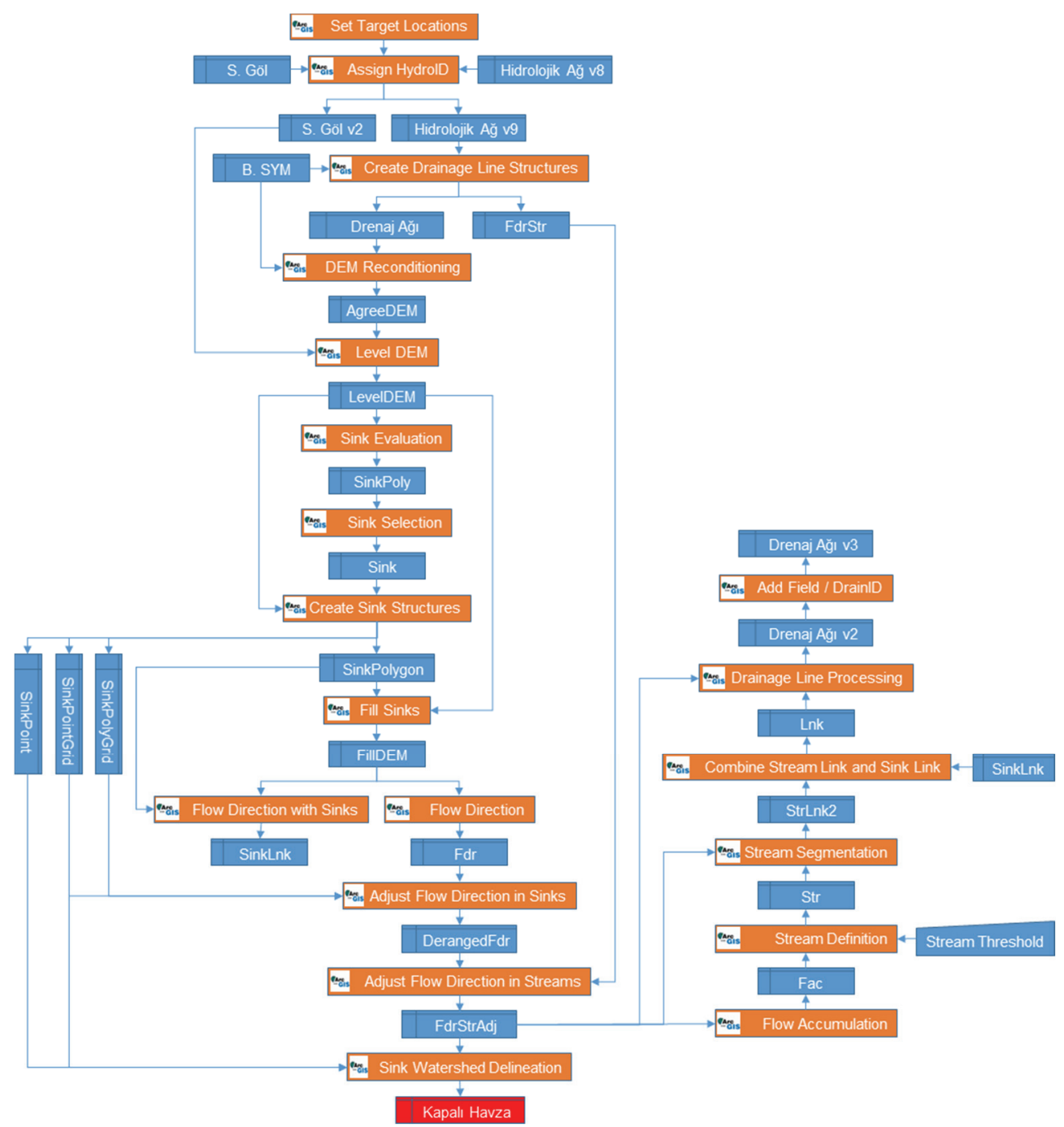

Şekil 2 - Hidrolojik Analiz 1: Kapalı havza sinırı ve drenaj çizgilerinin türetilmesi (Kısaltmalar: Bütünleşik (B.), Seçilen (S.), Versiyon (v); Renkler: Turuncu (ArcGIS Araçları), Mavi (Girdiler ve Çıktılar), Kırmızı (Sonuç Ürün))

\subsection{Hidrolojik Analiz 2: Havza ve Alt Havza Sınırlarının Türetilmesi}

Havza ve alt havza sınırlarının türetilmesine ilişkin akış diyagramı Şekil 3'te görünmektedir. Havza sınırlarını belirlemede kullanılacak çıkış (mansap) noktalarını manuel değil de yarı otomatik belirlemek için şöyle bir yol izlenmiştir: ArcHydro Drainage Point Processing aracıyla drenaj noktaları belirlenmiştir. Bu noktalardan DrainID değeri Null olanlar (iki veya daha fazla çizginin birleştĭgi nokta olmayanlar) seçilmiş ve BatchPoint olarak kaydedilmiştir. 
Batı Akdeniz Havzası Sınırlarının Yüksek Doğrulukla Belirlenmesi

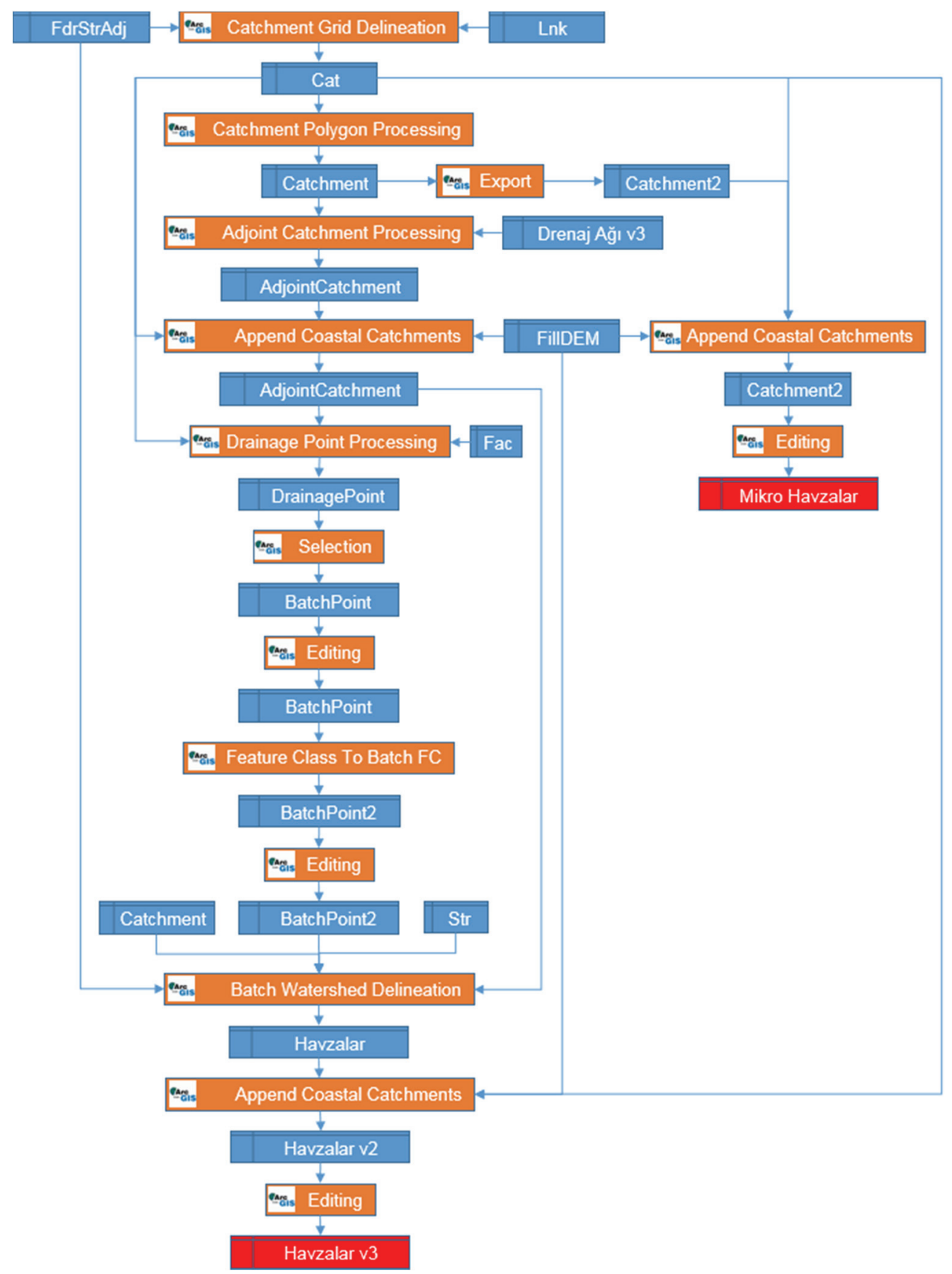

Şekil 3 - Hidrolojik Analiz 2: Havza ve alt havza sınırlarının türetilmesi (Kisaltmalar: Versiyon (v); Renkler: Turuncu (ArcGIS Araçları), Mavi (Girdiler ve Çıktılar), Kırmızı (Sonuç Ürünler)) 
Ancak bu noktaların tamamının denize ulaşan çizgilerin uç noktaları veya kapalı havzadaki göle ulaşan çizgilerin son noktaları olmadığı görülmüştür. Bu nedenle, bahsedilen nitelikte olmayan noktalar silinmiştir. Kalan noktalar, ArcHydro Feature Class To Batch FC araciyla, istenen (ArcHydro Batch Watershed Delineation araciyla kullanilabilecek nitelikte) noktalara dönüştürülmüştür. Ayrıca, kapalı havzadaki göle ulaşan çizgilerin sonlarında yer alan noktaların ScrType öznitelik değerleri 1 olarak değiştirilmiş ve böylece çıkış (outlet) değil, göle giriş (inlet) noktaları olarak tanımlanmıştır.

Bu çalışmada kullanılan veriler, Batı Akdeniz Havzası sınırının bir miktar dışına taştığı için ArcHydro Batch Watershed Delineation ve Append Coastal Catchments araçlarıyla belirlenen havzalar arasında Büyük Menderes, Burdur ve Antalya Havzası sınırları içinde kalan "havza parçaları" da vardır. Bu "havza parçaları" silinmiştir. Ayrıca, sahil boyunca bazı havzalar kaynaştırılmıştır. Böylece Batı Akdeniz Havzasının birinci düzey alt havzaları elde edilmiştir. Ayrıca, Batı Akdeniz Havzası sınırı dışında kalan su toplama alanları (Catchments) silinmiş ve geriye kalanlar Batı Akdeniz Havzası'nın mikro havzaları olarak kaydedilmiştir. Son olarak, Batı Akdeniz Havzası sınırı dışında kalan drenaj çizgileri silinmiş ve geriye kalanlar Batı Akdeniz Havzası'nın drenaj ağı (StreamNetwork) olarak kaydedilmiştir.

Akarsu ağının, drenaj alanları ile bağlantılı bir şekilde düzenlenebilmesi için, "European Rivers and Catchments Coding System / ERICA-CS" ve "European Catchments and Rivers Network Systems / ECRINS” çalışmalarında da kullanılan Pfafstetter yöntemi kullanılmıştır. Bu yöntemin iki temel kuralı aşağıdaki gibi ifade edilebilir (Şekil 4).

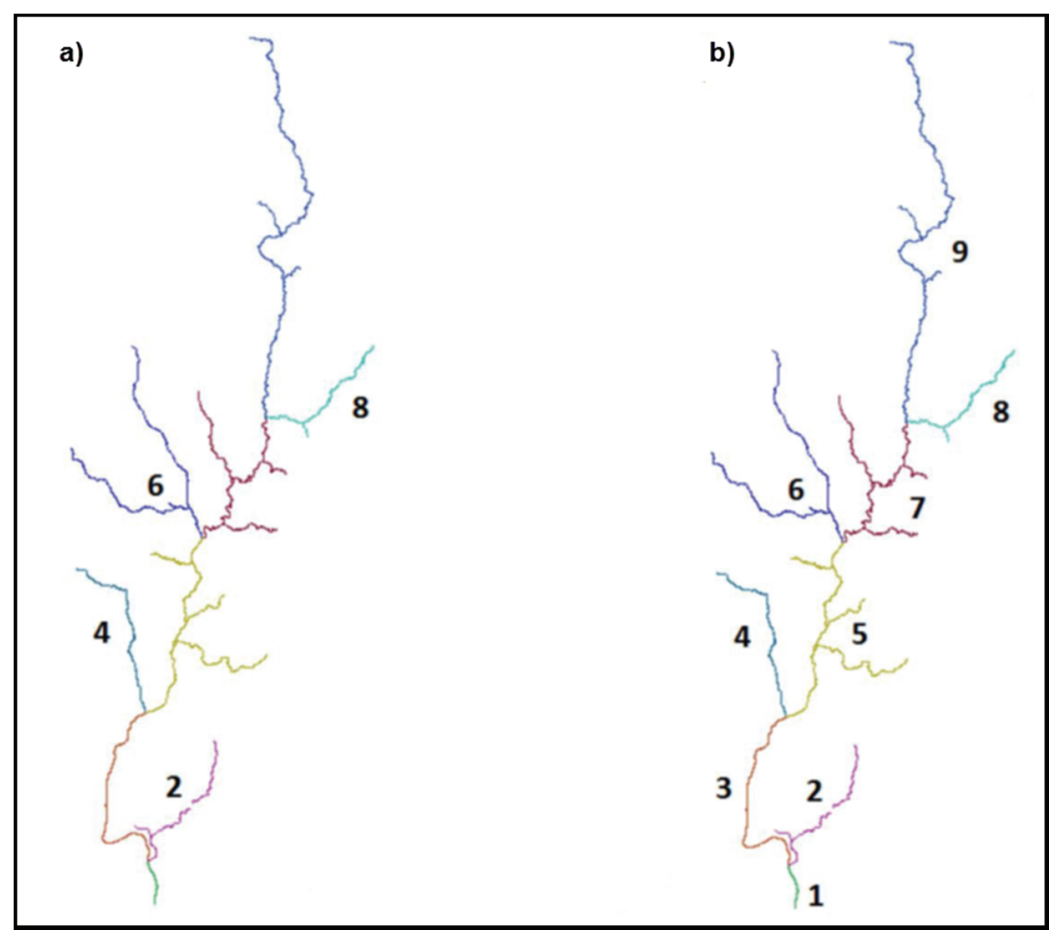

Şekil 4 - Pfafstetter yönteminin iki temel kuralı 
Kural 1: En yüksek 4 su toplama alanındaki (en büyük drenaj alanındaki) akarsu kolları mansaptan membaya doğru artacak şekilde tek haneli çift sayılarla $(2,4,6,8)$ numaralandırılır (Şekil 4a).

Kural 2: Ana kol boyunca yer alan geçiş havzalarındaki (inter-basin) akarsu kolları yine mansaptan membaya doğru artacak şekilde tek haneli tek sayılarla $(1,3,5,7,9)$ numaralandırılır (Şekil 4b). Denize dökülen kolun kodu daima 1'dir. Memba tarafındaki en uzun kolun kodu daima 9'dur. Geçiş havzası sayısı 5'ten az olması durumunda bile memba tarafındaki en uzun kolun kodu daima 9 olur.

Birinci ve ikinci kural uygulandığında birinci düzey kodlama gerçekleştirilmiş olur. Birinci düzey kapalı havzalara ise 0 kodu atanır [33].

\subsection{Havza Sinırı Karesel Ortalama Yatay Konum Hatasının Hesaplanması}

Türetilen havzaların karesel ortalama yatay konum hataları aşağıdaki bağıntıyla hesaplanmıştır.

$m_{l}=\sqrt{\frac{\sum_{i=1}^{n} d_{i}^{2}}{n}}$

Bu bağıntıda; $d_{i}$, kesin (doğru olarak kabul edilen) havza sınırını temsil eden çizgiye ait her bir nokta (ölçü noktası) ile türetilen havza sınırını temsil eden çizgi arasındaki yatay konum farkıdır. $n$ ise ölçü (yatay mesafe) ya da ölçü noktası sayısıdır. $d_{i}$ mesafeleri AutoCAD'in makro programlama dili olan AutoLISP ile yazılan bir program (rmse.lsp) yardımıyla otomatik ölçülmüş ve bir Excel sayfasına yazdırılmıştır. Karesel ortalama yatay konum hatası $\left(m_{l}\right)$ bu ölçülerle Excel'de hesaplanmıştır. Karesel ortalama yatay konum hatası, seçilen üç havza verisi ile hesaplanmıştır. Seçilen havza sınırları HGK'da görev yapan deneyimli bir operatör tarafından, özellikleri Bölüm 2.1'de açıklanan hava fotoğrafları kullanılarak ortaya konulan stereo modeller üzerinde dikkatlice üç boyutlu olarak çizilmiştir. Bu nedenle, operatör tarafından çizilen havza sınırlarının yatay (planimetrik) ve düşey (yükseklik) konum doğruluğu, aynı fotoğraflardan kıymetlendirilen TOPO25 veri tabanlarındaki hidrografya verilerinin yatay (planimetrik) ve düşey (yükseklik) konum doğruluğu ile aynıdır (\% 95 güven düzeyinde sırasıyla $\pm 4 \mathrm{~m}$ ve $\pm 3 \mathrm{~m}$ ). Bu $3 \mathrm{~B}$ çizgiler kesin havza sınırları olarak kabul edilmiştir. Akış diyagramı Şekil 5'te görünen rmse.lsp programının algoritması aşağıdaki gibi özetlenebilir.

1. Excel'i aç.

2. Ölçü noktalarının yerleştirileceği katmanı oluştur.

3. Kesin havzayı temsil eden çizgiyi al.

4. Çizgiyi meydana getiren ardışık doğru parçalarının birleşim yerlerinde (vertices) nokta nesneler (ölçü noktaları, $P_{i}, i=1,2, \ldots, k$ ) meydana getir.

5. Bir kesişim yerinde birden fazla ölçü noktası meydana getirilmişse, biri hariç diğerlerini sil $\left(P_{i}, i=1,2, \ldots, n\right)$.

6. Ölçü noktalarını bir diziye yerleştir. 


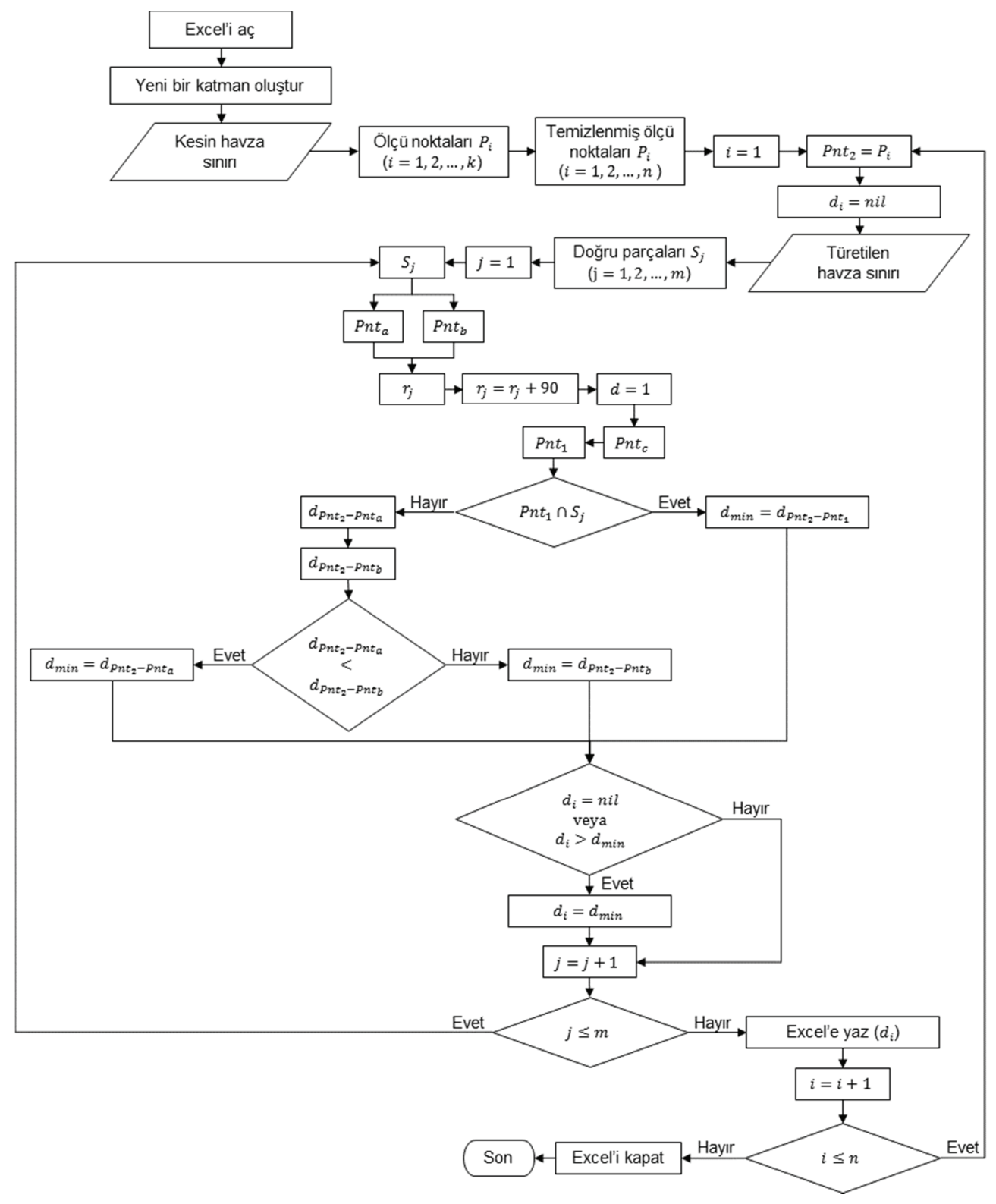

Şekil 5 - RMSE algoritmasının akış diyagramı

7. Diziden birinci ölçü noktasını al.

8. Türetilen havzayı temsil eden çizgiyi al.

9. Bu çizgiyi meydana getiren doğru parçalarından $\left(S_{j}, \mathrm{j}=1,2, \ldots, m\right)$ birincisini al. 
10. Bu doğru parçasının uç noktalarını $\left(P n t_{a}\right.$ ve $\left.P n t_{b}\right)$ al.

11. Bu iki nokta arasındaki açıyı $\left(r_{j}\right)$ hesapla.

12. Bu açıya $90^{\circ}$ ilave ederek yeni doğru parçasının doğrultu açısını hesapla.

13. Ölçü noktasından bu doğrultu boyunca 1 birim uzaklıkta $(d=1)$ yeni bir nokta $\left(P n t_{c}\right)$ tanımla.

14. Bu nokta ve ölçü noktasıyla tanımlı doğru parçası ile türetilen havzayı temsil eden çizginin ele alınan doğru parçasının gerçek ya da uzantıda kesişim noktasını $\left(P n t_{1}\right)$ belirle.

15. Kesişim noktası, türetilen havzayı temsil eden çizginin ele alınan doğru parçası üzerinde ise $\left(P n t_{1} \cap S_{j}\right)$ kesişim noktası ile ölçü noktası arasındaki yatay mesafeyi minimum mesafe $\left(d_{\min }=d_{P n t_{2}-P n t_{1}}\right)$ olarak kaydet. Değilse, kesişim noktası ile türetilen havzayı temsil eden çizginin ele alınan doğru parçasının uç noktaları arasındaki mesafeleri $\left(d_{P n t_{2}-P n t_{a}}\right.$ ve $\left.d_{P n t_{2}-P n t_{b}}\right)$ hesapla ve kisa olanı minimum mesafe olarak kaydet.

16. Minimum mesafeyi $\left(d_{\text {min }}\right)$ yatay konum farkı $\left(d_{i}\right)$ ile karşılaştır. Küçük ise $\left(d_{i}>\right.$ $\left.d_{\text {min }}\right)$ minimum mesafe değerini yatay konum farkı olarak kaydet $\left(d_{i}=d_{\text {min }}\right)$.

17. Türetilen havzayı temsil eden çizginin geriye kalan doğru parçalarıyla 10uncu ve 16ncı adımlar arasındaki işlemleri tekrarla.

18. Yatay konum farkı değerini $\left(d_{i}\right)$ Excel'e yaz.

19. Ölçü noktaları dizisindeki geriye kalan noktalarla 7 nci ve 18 inci adımlar arasındaki işlemleri tekrarla.

20. Excel'i kapat.

\subsection{SYM Karesel Ortalama Düşey Konum (Yükseklik) Hatasının Hesaplanması}

Bölüm 2.11'de açıklandığı gibi, rmse.lsp programı ile havza sınırı karesel ortalama yatay konum hatası hesaplanırken; dördüncü adımda, çizgiyi (havza sınırı) meydana getiren ardışık doğru parçalarının birleşim yerlerinde (vertices) nokta nesneler meydana getirilmekte, beşinci adımda ise bir kesişim yerinde birden fazla nokta meydana getirilmişse, biri hariç diğerleri silinmektedir. HGK'da görev yapan deneyimli bir operatör tarafından stereo modeller üzerinde çizilen bu çizgiler üç boyutlu olduğu için bu noktalar da üç boyutludur. SYM karesel ortalama düşey konum (yükseklik) hatası hesabında; bu noktaların yükseklikleri "kesin değerler”, bu noktalara karşılık gelen (bu noktaların üzerinde yer aldığı) SYM hücrelerinin değerleri ise "ölçüler" olarak kabul edilmiş ve aşağıdaki bağıntı kullanılmıştır.

$m_{h}=\sqrt{\frac{\sum_{i=1}^{n} d h_{i}^{2}}{n}}$

Bu bağıntıda; $d h_{i}$, ölçülerin kesin değerlerden farkları, $n$ ise ölçü (nokta) sayısıdır. 


\section{UYGULAMA SONUÇLARI}

Şekil 6 ve 7'de görünen pafta sınırları, coğrafi koordinat sisteminde konumlandırılmış özgün verilerin Albers alan koruyan konik projeksiyonda yeniden konumlandırılmasının uzunluk ve açı deformasyonları bakımından sonuçlarını en yalın biçimde göstermektedir.

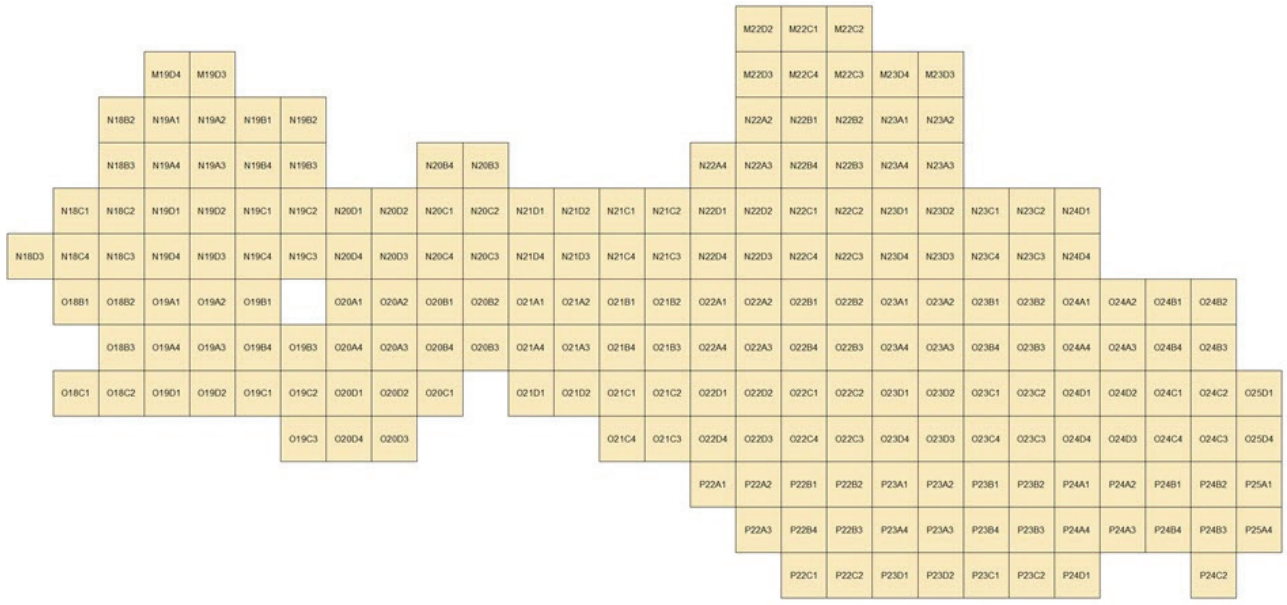

Şekil 6 - Coğrafi koordinat sisteminde konumlandırılmış özgün pafta sınırları

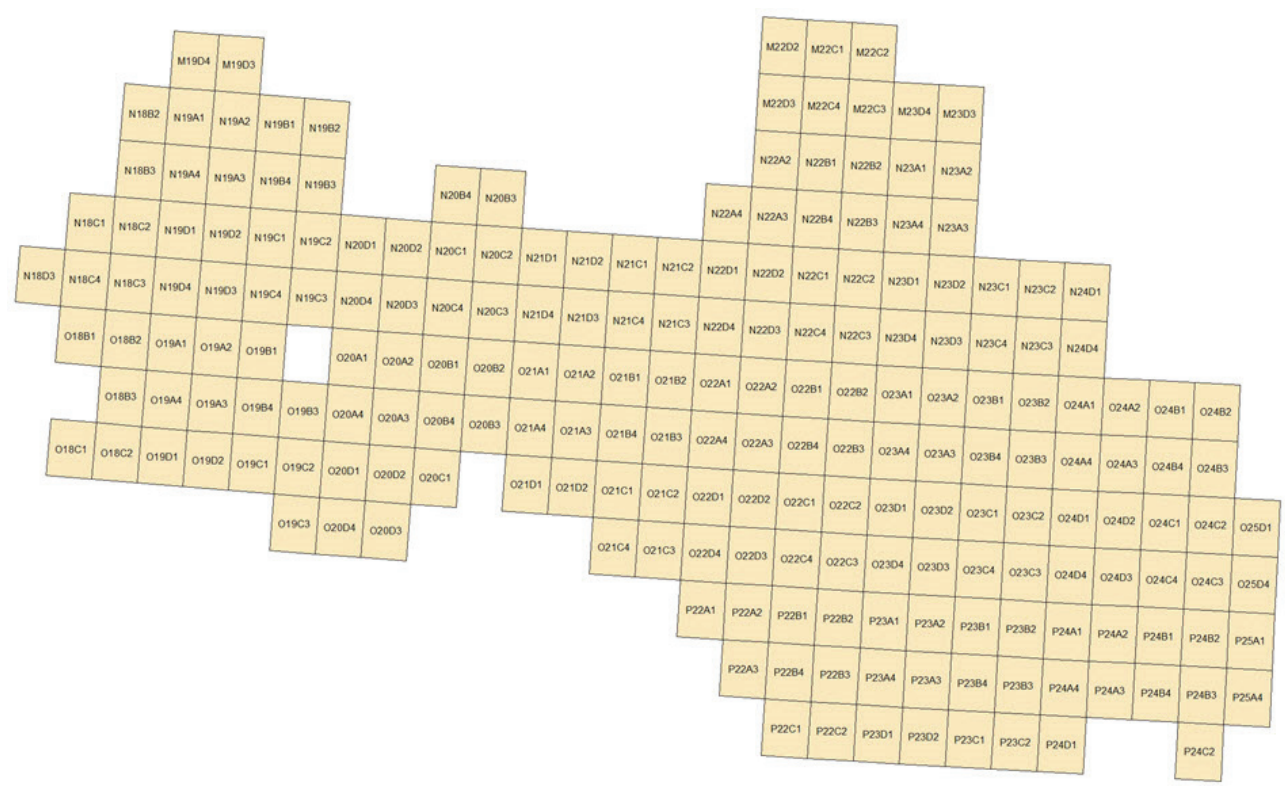

Şekil 7 - Albers alan koruyan konik projeksiyonda yeniden konumlandırılmış pafta sınırları 
Tersdere programı yardımıyla otomatik olarak tespit edilmiş ve düzeltilmiş dar dere ve kanal sayıları geometri türüne göre Tablo 1'de verilmiştir.

Tablo 1 - Aklş yönünün tersi yönünde çizilmiş 'polyline've 'line' türünde dar dere ve kanal saylart

\begin{tabular}{ccccc}
\hline \multirow{3}{*}{ Toplam } & \multicolumn{2}{c}{ Dar Dere } & \multicolumn{2}{c}{ Kanal } \\
\cline { 2 - 5 } & Polyline & Line & Polyline & Line \\
\cline { 2 - 5 } & 12,931 & 152 & 6082 & 397 \\
\hline
\end{tabular}

207 adet SYM'nin birleştirilmesiyle elde edilen bütünleşik SYM'ye ait istatistikler aşağıdaki gibidir.

$\begin{array}{ll}\text { Minimum } & : 0 \mathrm{~m} \\ \text { Maksimum } & : 3070.713 \mathrm{~m} \\ \text { Ortalama } & : 916.181 \mathrm{~m} \\ \text { Standart Sapma } & : 605.676 \mathrm{~m}\end{array}$

Hidrolojik ăg, arc-node veri yapısında 1001 adet akarsu ve 36 adet göl nesnesinden meydana gelmektedir. Akarsu nesnelerinin tamamı akış yönünde ve membalardan itibaren sürekli alçalan çizgilerdir. Göl nesneleri sabit kotlu poligonlardır. Bütünleşik SYM ve hidrolojik ağ Şekil 8'de görünmektedir.

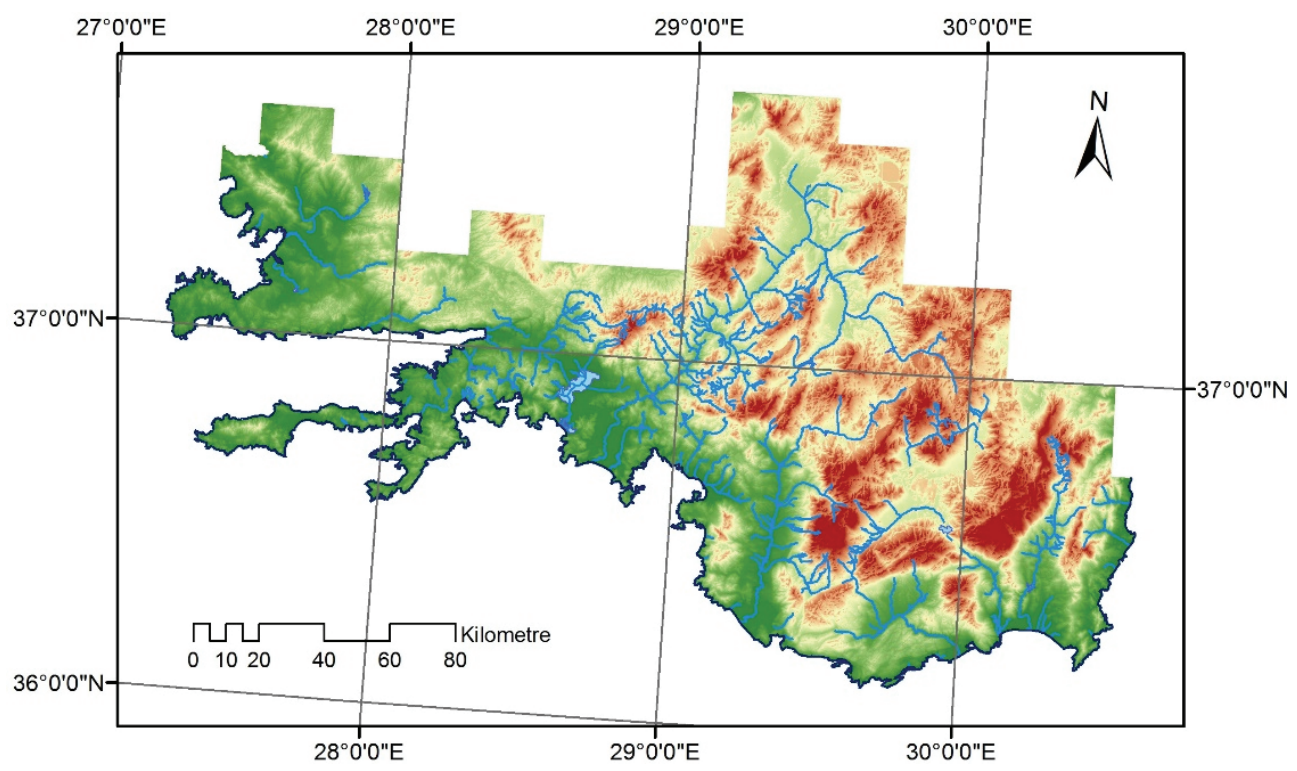

Şekil 8 - SYM ve hidrolojik ăg (arc-node veri yapısında 1001 adet akarsu ve 36 adet göl) 
ArcHydro Sink Evaluation aracıyla yüzölçümleri $100 \mathrm{~m}^{2}$ ile 53,887,400 $\mathrm{m}^{2}$ arasında değişen 58,772 adet çukur belirlenmiştir. Bunlardan biri de Avlan Gölü’dür. Avlan Gölü’ne karşıllık gelen çukur nesnesine dayalı olarak türetilen kapalı havza sınırı, Avlan Gölü'ne karşılık gelen çukur nesnesi haricindeki tüm çukurların doldurulmasıyla elde edilen hidrolojik SYM ve Avlan Gölü Şekil 9'da görünmektedir.

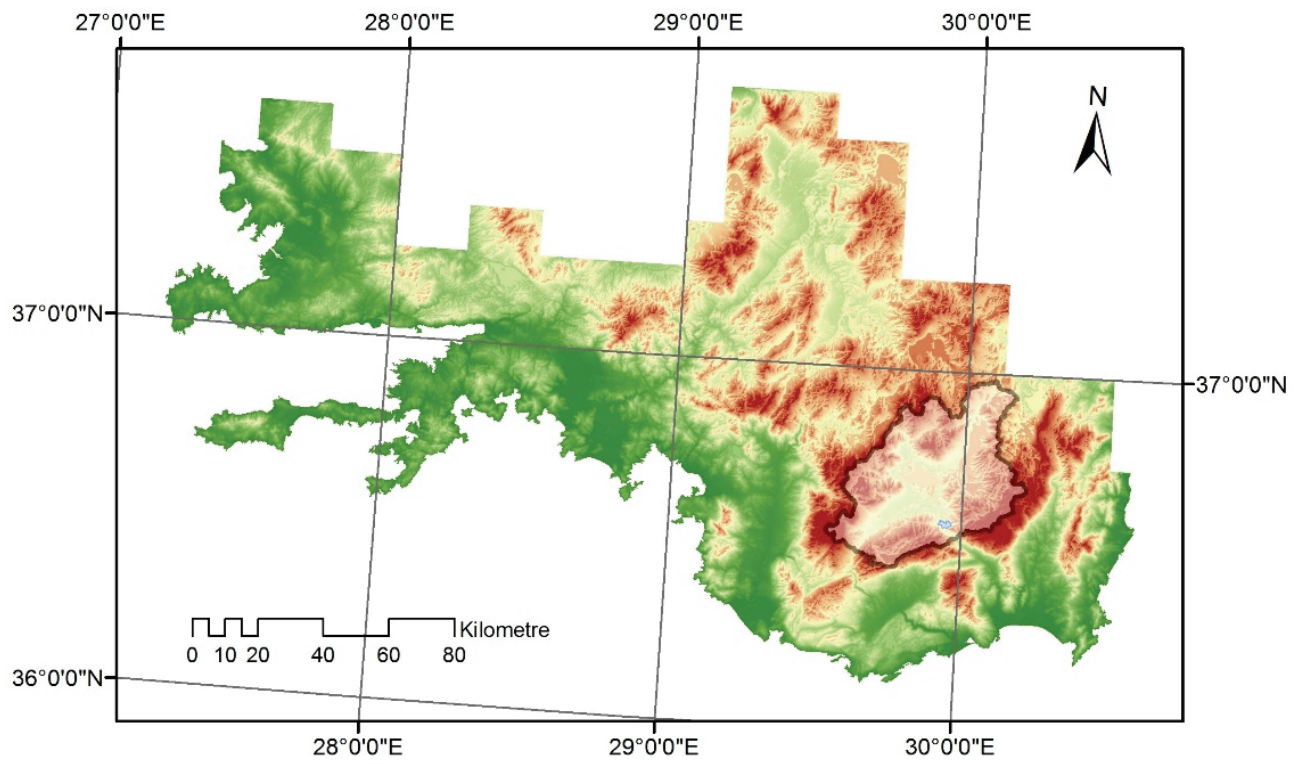

Şekil 9 - Kapalı havza, hidrolojik SYM ve Avlan Gölü

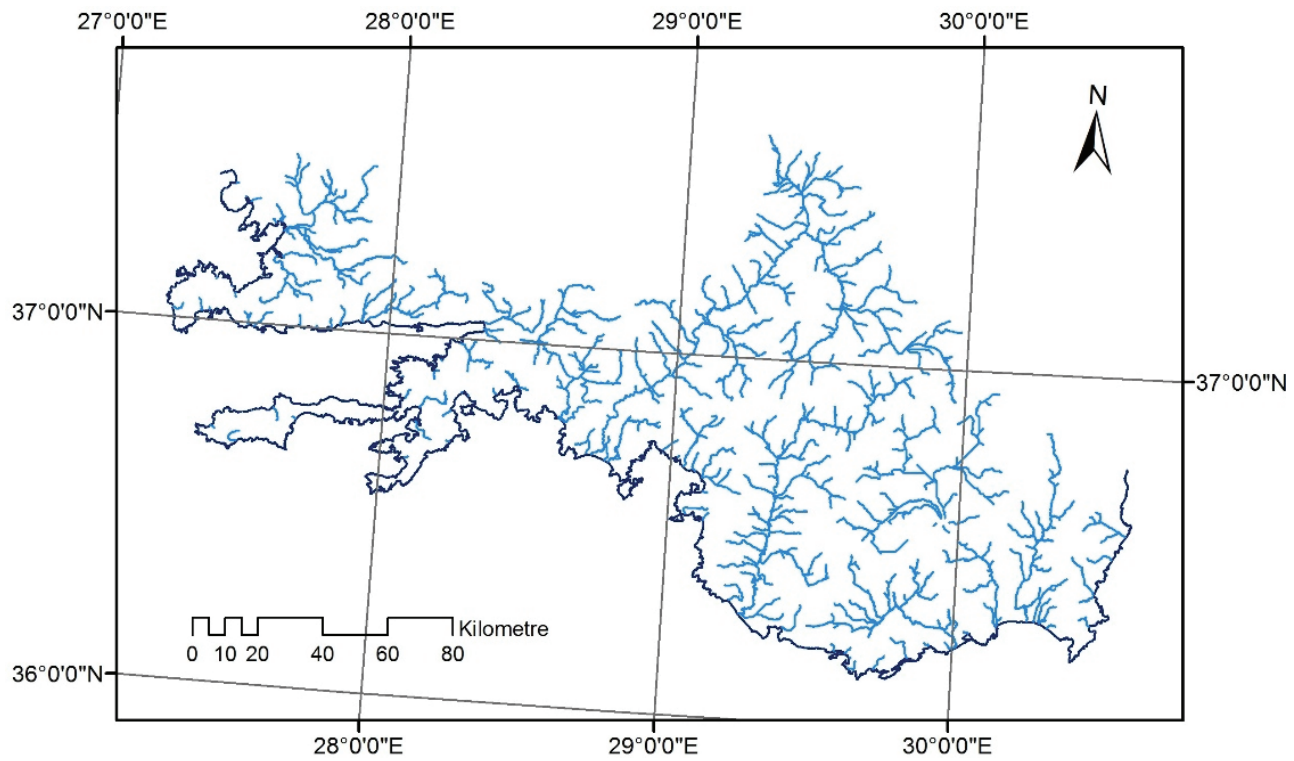

Şekil 10 - BeST drenaj ăgl 
BeST programı yardımıyla hesaplanan birikinti eşik değeri 117,622'dir. Bu eşik değere göre türetilen drenaj ağı (BeST drenaj ağı) Şekil 10'da görünmektedir. Toplam uzunluğu 4,586,301.92 m olan bu ağ, arc-node veri yapısında 891 nesneden meydana gelmektedir.

BeST drenaj ağına dayalı olarak belirlenen birinci düzey alt havzalar Şekil 11'de görünmektedir. BeST havza setinde en küçük altıncı düzeyde alt havzalar yer almaktadır.

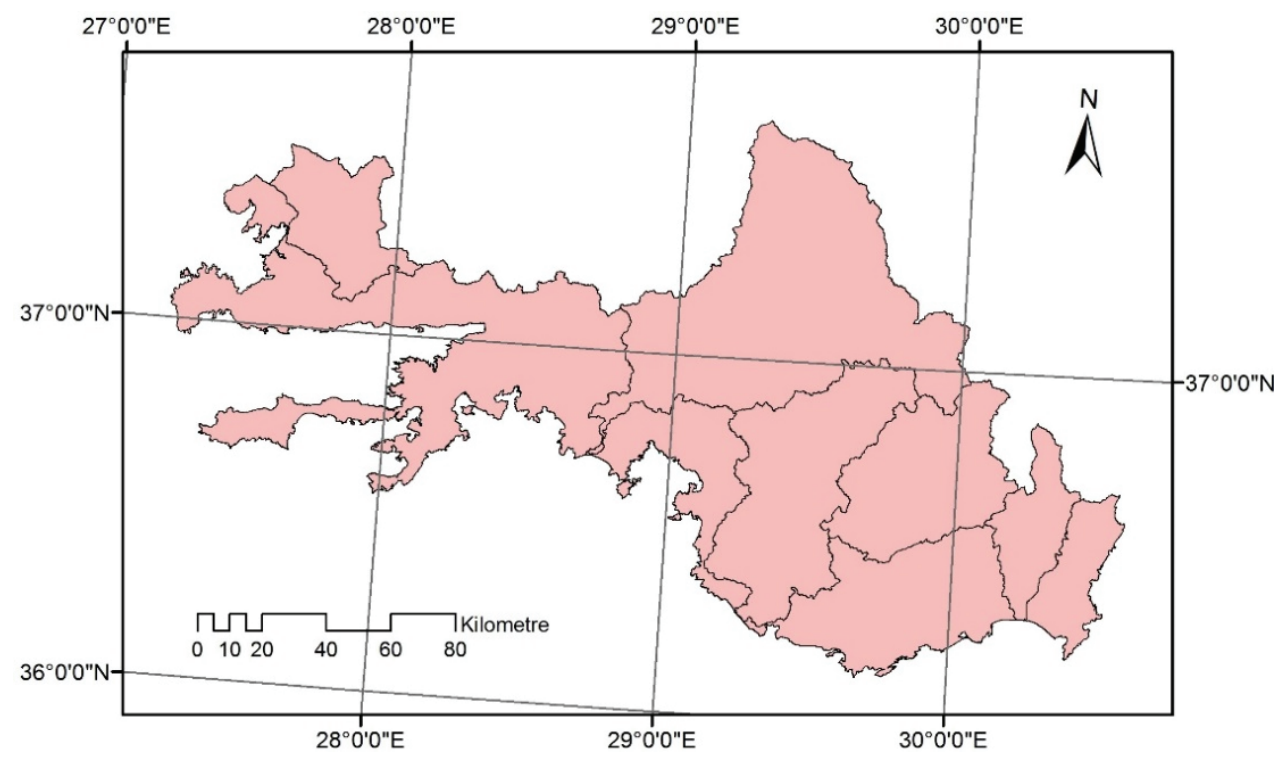

Şekil 11 - BeST birinci düzey alt havza sınırları

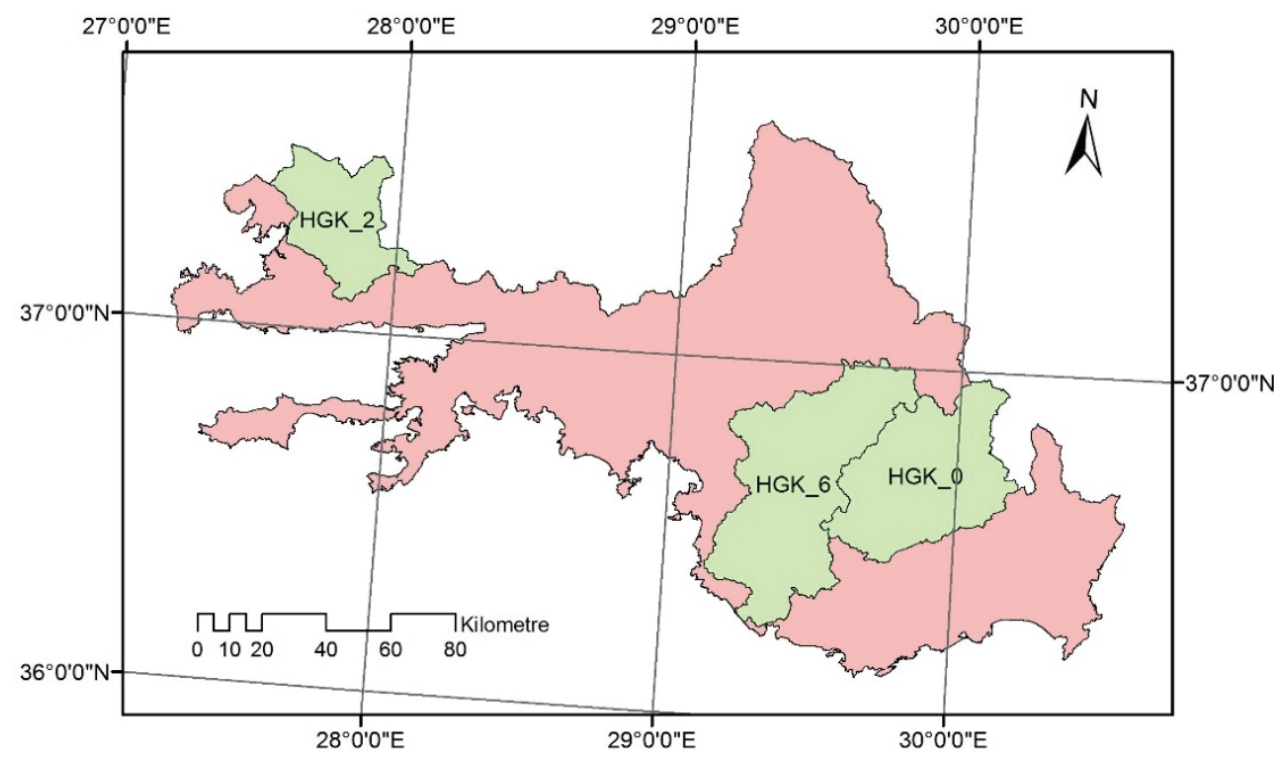

Şekil 12 - HGK'da çizilen alt havza sinırları (HGK_0, HGK_2 ve HGK_6) 
Türkay GÖKGÖZ, Mustafa ERDOĞAN, Kemal SEYREK, I. Murat OZULU

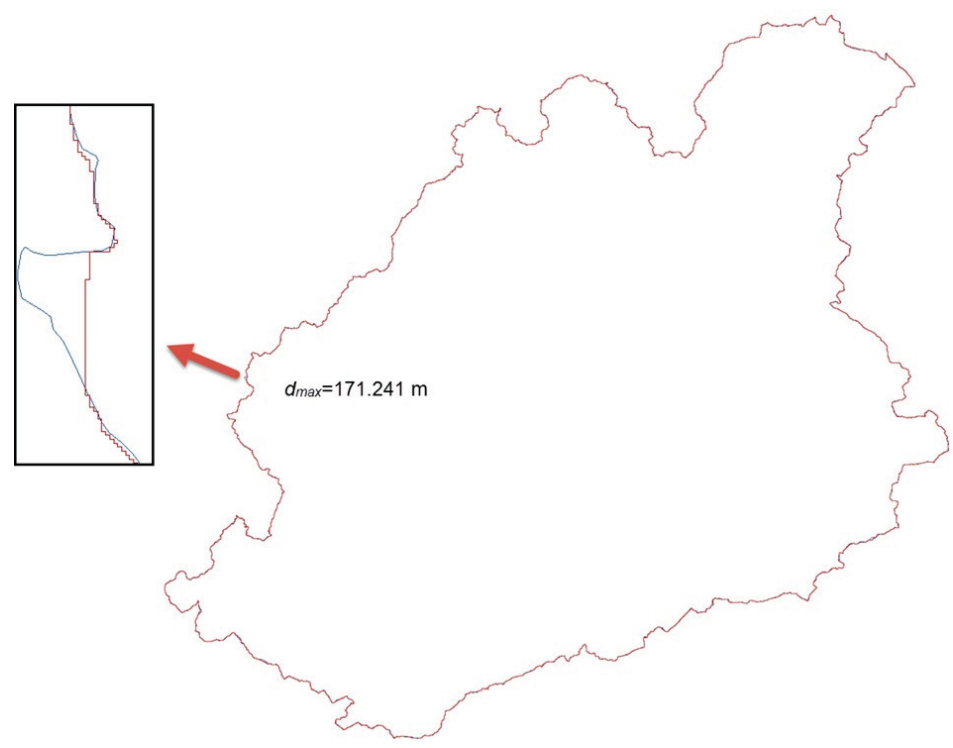

Şekil 13 - HGK_0 (mavi) ve BeST_0 (kirmızl) havza sinırları

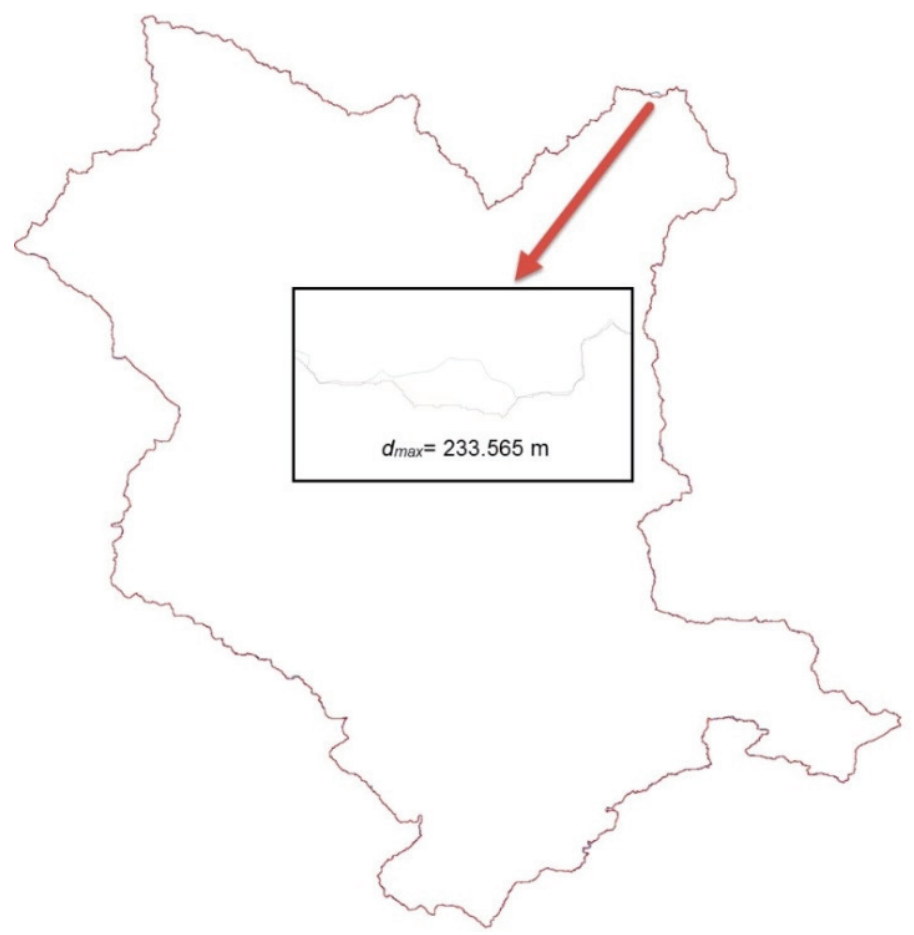

Şekil 14 - HGK_2 (mavi) ve BeST_2 (kirmizl) havza sinırlarl 
HGK' da görev yapan deneyimli bir operatör tarafından stereo modeller üzerinde dikkatlice üç boyutlu çizilen ve havza sınırı karesel ortalama yatay konum hatası hesabında kesin sınır olarak kullanılan üç havza (BeST değerleriyle türetilen birinci düzey havzalardan kıyı kodu 0, 2 ve 6'ya karşılık gelen üç havza) Şekil 12'de görünmektedir. Bundan sonra HGK'da çizilen bu üç alt havza kısaca HGK_0, HGK_2 ve HGK_6 adıyla anılacaktır. Benzer biçimde, BeST değeriyle türetilen alt havzalar ise BeST_0, BeST_2 ve BeST_6 adıyla anılacaktır.

HGK_0, HGK_2 ve HGK_6'nın nokta sayıları sirasiyla 8676, 10,838 ve 12,301'dir. HGK_0 ile BeST_0, HḠK_2 ile BesT _2 ve HGK_6 ile BeST_6 çakıştırılmış halde sırasıyla Şekil $\overline{13}$, 14 ve $15^{\prime}$ te görünmektedir. Karesel ortalama yatay konum hatasına ilişkin istatistikler Tablo 2'de verilmiştir.

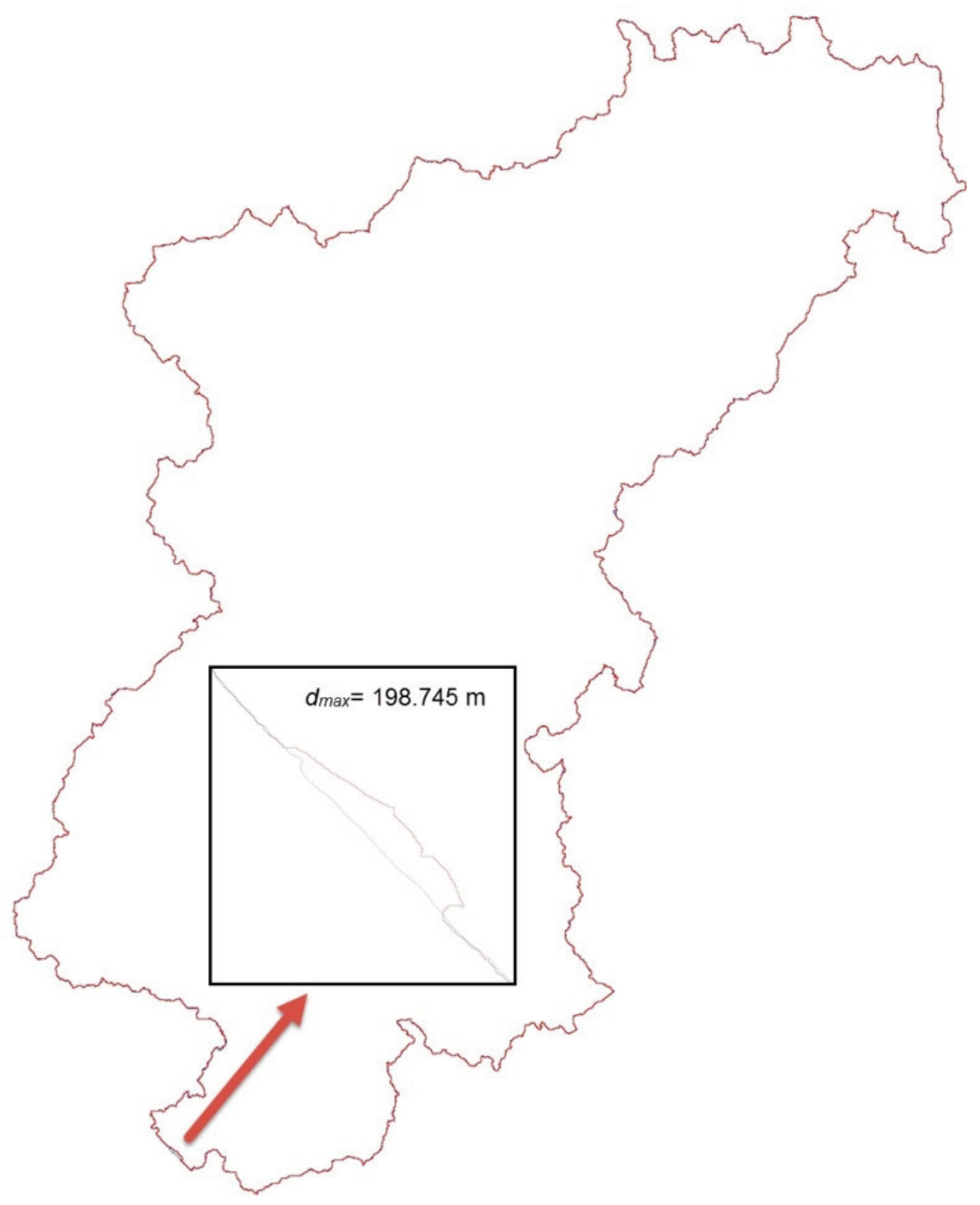

Şekil 15 -HGK_6 (mavi) ve BeST_6 (kırmızı) havza sınırları 
Tablo 2 - Karesel ortalama yatay konum hatasına ilişkin istatistikler

\begin{tabular}{lrrrr}
\hline Havza & Ölçü Sayıs1 & $d_{\min }[\mathrm{m}]$ & $d_{\max }[\mathrm{m}]$ & $m_{l}[\mathrm{~m}]$ \\
\hline BeST_0 & 8676 & 0.002 & 171.241 & 14.36 \\
BeST_2 & 10,838 & 0.0003 & 233.565 & 16.14 \\
BeST_6 & 12,301 & 0.002 & 198.745 & 14.80 \\
\hline
\end{tabular}

Aşağıdaki bağıntıyla, bu çalışmada türetilen üç alt havza için hesaplanan karesel ortalama yatay konum hatalarının ağılıklı ortalaması alınarak, bu çalışmada türetilen tüm havzalar için bir ağırlıklı karesel ortalama yatay konum hatası hesaplanmıştır.

$\bar{m}_{l}=\frac{\sum_{j=1}^{3} w_{j} m_{l_{j}}}{\sum_{j=1}^{3} w_{j}}$

Bu bağıntıda; $w_{j}$, ölçü sayıları $\left(w_{1}=8676, w_{2}=10,838\right.$ ve $\left.w_{3}=12,301\right)$ ve $m_{l_{j}}$, karesel ortalama yatay konum hataları $\left(m_{l_{1}}=14.36, m_{l_{2}}=16.14\right.$ ve $\left.m_{l_{3}}=14.80\right)$ olmak üzere, ağırlıklı karesel ortalama yatay konum hatası $\bar{m}_{l}=15.14 \mathrm{~m}$ olarak hesaplanmıştır.

BeST havzalarının ortalama yatay konum doğruluğu için eşik değer ise aşağıdaki bağıntıyla hesaplanmıştır [34].

$M_{l}=(2 \times P)+m_{l}$

Bu bağıntıda; $P$, hücre büyüklüğü (SYM çözünürlüğü) ve $m_{l}$, SYM üretiminde kullanılan verilerin ortalama yatay konum doğruluğudur. $\mathrm{Bu}$ çalışmada kullanılan verilerin ortalama yatay konum doğruluğu $\mp 4.00$ m'dir. Buna göre, $M_{l}=(2 \times 10)+4= \pm 24$ m'dir.

Ayrıca, American Society for Photogrammetry and Remote Sensing (ASPRS) standartlarına göre ortalama yatay konum doğruluğu için eşik değer aşağıdaki bağıntıyla da hesaplanabilir [35].

$M_{l}=C \times P$

Bu bağıntıda; $P$, hücre büyüklüğü (SYM çözünürlüğü) ve $C$, sınıf değeridir. ASPRS standartlarına göre doğruluk, yapılan çalışmanın niteliğine bağlı olarak belirlenmektedir ve çalışmalar üç sınıfta toplanmıştır: (1) Yüksek doğruluk gerektiren çalışmalar, (2) standart haritalama ve CBS çalışmaları ve (3) görselleştirme ve yüksek doğruluk gerektirmeyen çalışmalar. Bu çalışma ikinci sınıfa girmektedir ve bu nedenle bağıntıdaki $C$ parametresinin değeri 2'dir. Buna göre, $M_{l}=2 \times 10= \pm 20$ m'dir.

Sonuç olarak, BeST havzalarının ağılıklı karesel ortalama yatay konum hatası $\left(\bar{m}_{l}=\right.$ $15.14 \mathrm{~m})$ yukarıda hesaplanan her iki eşik değerden de $\left(M_{l_{1}}= \pm 24 \mathrm{~m}, M_{l_{2}}= \pm 20 \mathrm{~m}\right)$ küçük olduğu için BeST havzalarının ortalama yatay konum doğruluğunun oldukça yüksek olduğu söylenebilir. 
HGK_0, HGK_2 ve HGK_6 havza sinırlarında meydana getirilen sirasıyla 8676, 10,838 ve 12,301 noktanın yükseklikleri (kesin değerler, $\bar{h}_{i}$ ), bu noktalara karşılık gelen SYM hücrelerinin değerleri (ölçüler, $\left.h_{i}\right)$ ve yükseklik farklarına $\left(d h=h_{i}-\bar{h}_{i}\right)$ göre belirlenen minimum yükseklik farkları $\left(d h_{\text {min }}\right)$, maksimum yükseklik farkları $\left(d h_{\text {max }}\right)$ ve karesel ortalama düşey konum hataları $\left(m_{h}\right)$ Tablo 3 'te verilmiştir.

Tablo 3 - Karesel ortalama düşey konum hatasına ilişkin istatistikler

\begin{tabular}{lrrrr}
\hline Havza & Ölçü Sayıs & $d h_{\min }[\mathrm{m}]$ & $d h_{\max }[\mathrm{m}]$ & $m_{h}[\mathrm{~m}]$ \\
\hline HGK_0 & 8676 & 0.00 & 20.90 & 2.44 \\
HGK_2 & 10,838 & 0.00 & 32.09 & 2.83 \\
HGK_6 & 12,301 & 0.00 & 20.90 & 2.63 \\
\hline
\end{tabular}

Aşağıdaki bağıntıyla, HGK_0, HGK_2 ve HGK_6 havzasına dayalı olarak hesaplanan SYM karesel ortalama düşey konum hatalarının ağırlıklı bütünleşik SYM için bir ağırlıklı karesel ortalama düşey konum hatası hesaplanmıştır.

$\bar{m}_{h}=\frac{\sum_{j=1}^{3} w_{j} m_{h_{j}}}{\sum_{j=1}^{3} w_{j}}$

Bu bağıntıda; $w_{j}$, ölçü sayıları $\left(w_{1}=8676, w_{2}=10,838\right.$ ve $\left.w_{3}=12,301\right)$ ve $m_{h_{j}}$, karesel ortalama düşey konum hataları $\left(m_{h_{1}}=2.44, m_{h_{2}}=2.83\right.$ ve $\left.m_{h_{3}}=2.63\right)$ olmak üzere, ağırlıklı karesel ortalama düşey konum hatası $\bar{m}_{h}=2.65 \mathrm{~m}$ olarak hesaplanmıştır.

SYM üretiminde kullanılan verilerin ortalama düşey konum doğruluğu, SYM'nin ortalama düşey konum doğruluğu için bir eşik değer olarak kabul edilebilir. Bu çalışmada, SYM üretiminde kullanılan verilerin ortalama düşey konum doğruluğu $\mp 3.00 \mathrm{~m}$ 'dir. Ayrıca, ASPRS, National Map Accuracy Standard (NMAS) [36] ve National Standard for Spatial Data Accuracy (NSSDA) [37] standartlarına göre, SYM üretiminde kullanılan yükseklik eğrilerinin eş yükseklik değerinin yarısı, ortalama düşey konum doğruluğu için eşik değer olarak kabul edilmektedir. Bu çalışmada kullanılan yükseklik eğrilerinin eş yükseklik değeri 10 m'dir. Buna göre, ortalama düşey konum doğruluğu için eşik değer $M_{h}=10 / 2=$ \pm 5 m'dir.

Sonuç olarak, BeST havzalarının ağırlıklı karesel ortalama düşey konum hatası $\left(\bar{m}_{h}=\right.$ $2.65 \mathrm{~m})$ yukarıda hesaplanan her iki eşik değerden de $\left(M_{h_{1}}= \pm 3 \mathrm{~m}, M_{h_{2}}= \pm 5 \mathrm{~m}\right)$ küçüktür. Bu nedenle BeST havzalarının ortalama düşey konum doğruluğunun da oldukça yüksek olduğu söylenebilir.

Son olarak, hidrolojik analizde SYM çözünürlüğünün etkisini göstermek amacıyla, DSİ tarafından 90 m çözünürlüğe sahip SRTM (Shuttle Radar Topography Mission) 3 Arc SYM kullanılarak üretilen drenaj ağı (DSİ drenaj ağı) ve birinci düzey alt havza sınırları (DSI birinci düzey alt havza sınırları), bu çalışmada üretilen drenaj ağı (BeST drenaj ağı) ve birinci düzey alt havza sınırları (BeST birinci düzey alt havza sınırları) ile karşılaştırılmıştır. Ayrıca, DSİ havzalarının ağırlıklı ortalama yatay konum hatası hesaplanmış ve hem ortalama yatay 
konum hatası eşik değeri ile hem de BeST havzalarının ağırlıklı karesel ortalama yatay konum hatası ile karşılaştırılmıştır.

DSİ drenaj ağı, toplam uzunluğu 6,213,223.21 m olan ve arc-node veri yapısında 1170 nesneden meydana gelen bir ağdır. Buna göre; BeST drenaj ağındaki nesne sayı (891), DSİ drenaj ağındaki nesne sayısının yaklaşık \% 76'sı; BeST drenaj ağının toplam uzunluğu $(4,586,301.92 \mathrm{~m})$ ise DSİ drenaj ağının toplam uzunluğunun yaklaşık \% 74'ü kadardır. Görsel karşılaştırma da yapılabilmesi için, BeST ve DSİ drenaj ağları çakıştırılmış halde Şekil 16'da gösterilmiştir.

BeST ve DSİ birinci düzey alt havza sınırları çakıştırılmış halde Şekil 17'de gösterilmiştir. Bej renkli havza, BeST birinci düzey alt havzalarında bulunmayan DSİ birinci düzey alt havzasıdır. Yeşil renkli havza ise BeST kapalı havzasını da içine alan DSİ açık havzasıdır. Bej ve yeşil renkli havzalar, BeST ve DSİ havzaları arasındaki başlıca fark olarak görünmektedir. $\mathrm{Bu}$ havzalar dışındaki havzalar arasında da kısmen farklar olduğu görünmektedir. Bunun nedeni, DSİ girdilerinin (1:25,000, 1:100,000 ve 1:250,000 ölçekli standart topoğrafik haritalardan meydana getirilen hidrolojik ağ ve $90 \mathrm{~m}$ çözünürlüklü SRTM) ve metodolojisinin, BeST girdilerinden (bu çalışmada üretilen hidrolojik ağ ve $10 \mathrm{~m}$ çözünürlüklü SYM) ve metodolojisinden farklı olmasıdır.

DSİ birinci düzey alt havza sınırları arasında BeST_0'a (kapalı havzaya) karşılık gelen bir havza bulunmadığı için hata hesabı HGK_2 ve HGK_6'ya karşılık gelen DSİ havzaları ile yapılmıştır. HGK_2 ile DSİ_2 çakıştırılmış halde Şekil 18'de görünmektedir. Minimum ve maksimum yatay konum farkları sırasıyla 0.006 m ve 1258.006 m'dir. 10,838 ölçüyle yapılan hesap sonucunda DSİ_'nin ortalama yatay konum hatası $m_{l}=145.39 \mathrm{~m}$ olarak bulunmuştur.

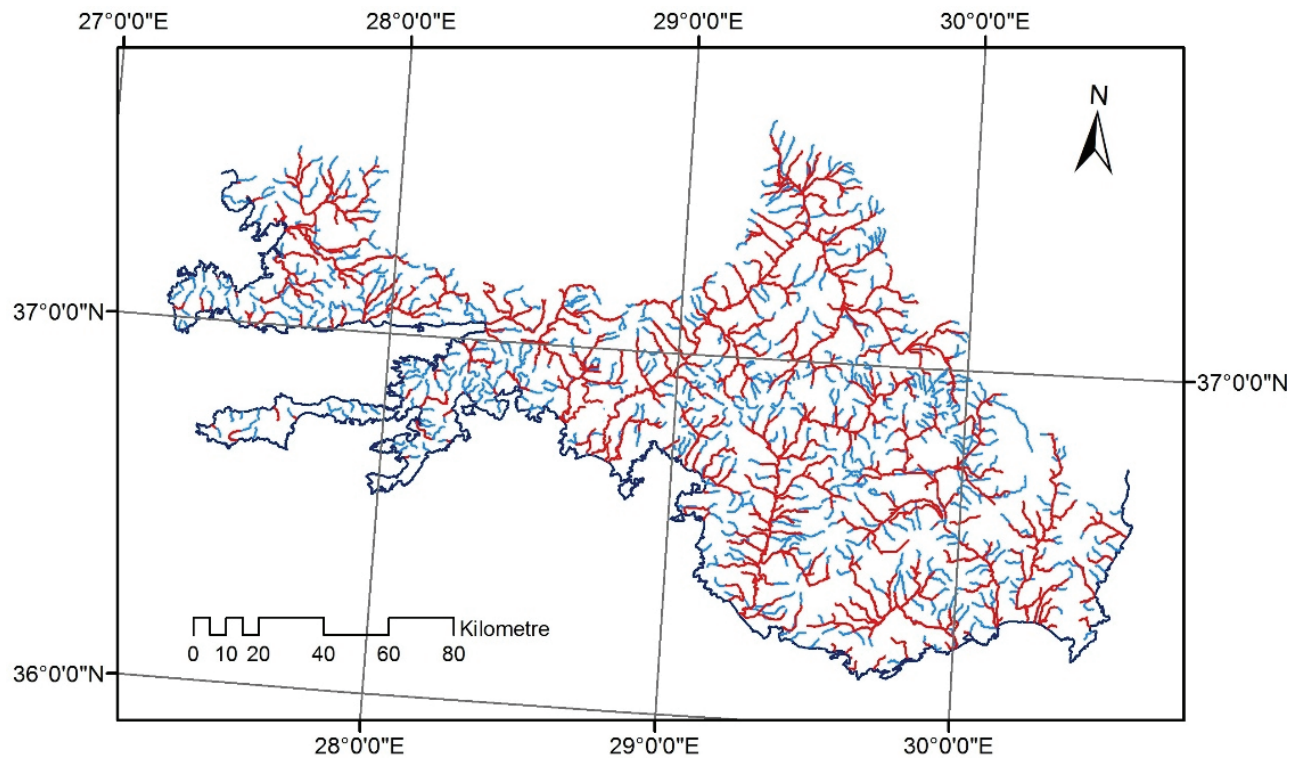

Şekil 16 - BeST (kırmızı) ve DSİ (mavi) drenaj ăgları 


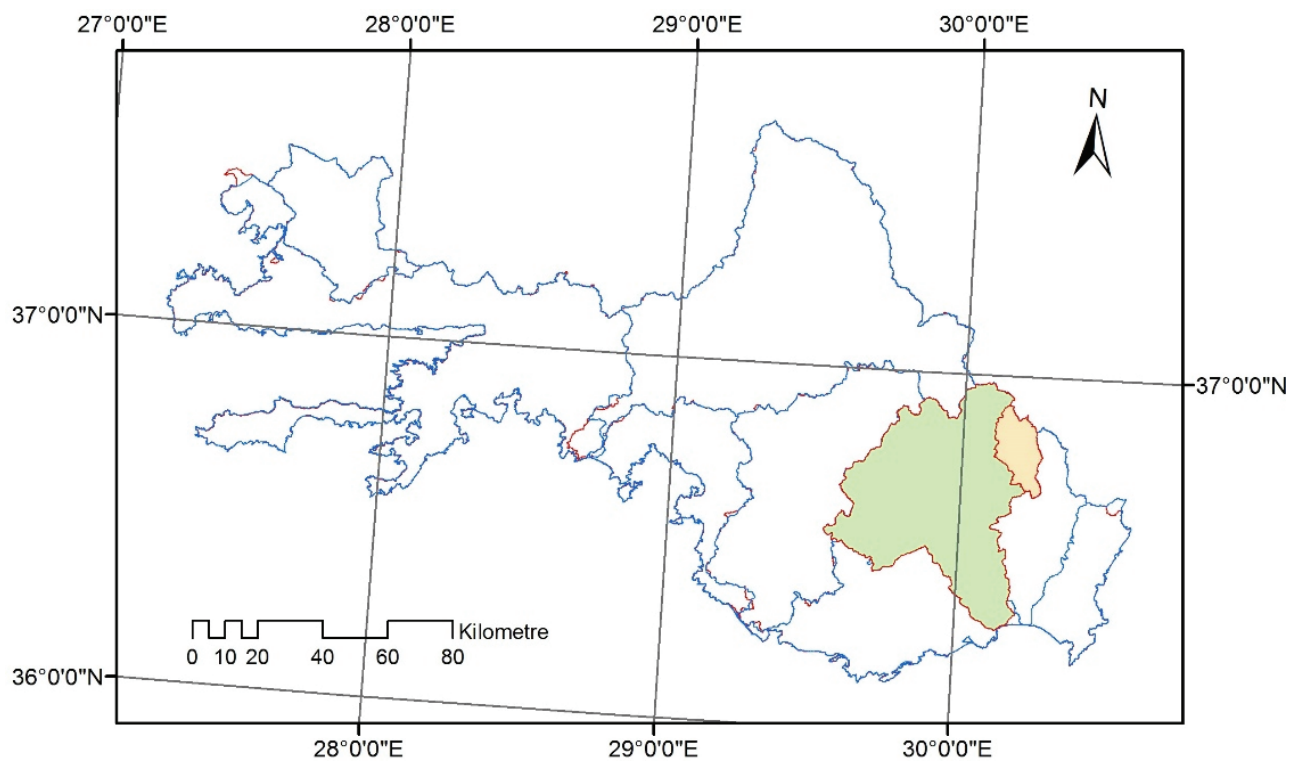

Şekil 17 - BeST (mavi) ve DSİ (kırmızı) birinci düzey havzaları: BeST kapalı havzasını da içine alan DSI açık havzası (yeşil) ve BeST havzalarında bulunmayan DSI havzası (bej)

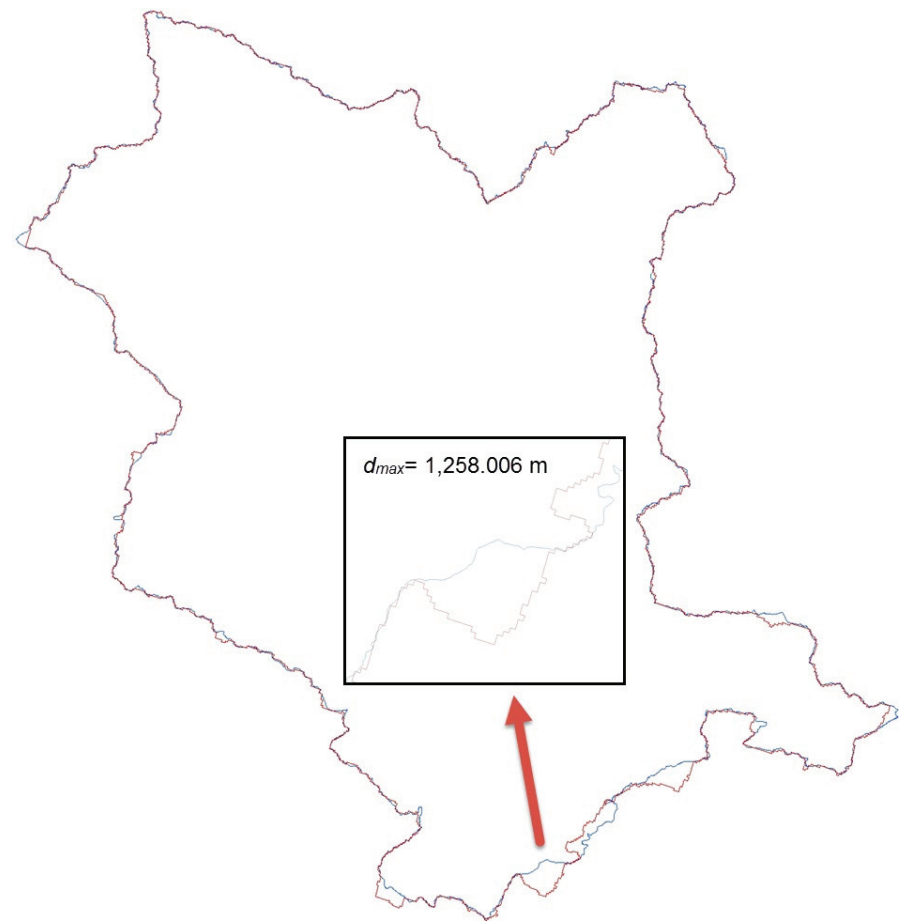

Şekil 18 -HGK_2 (mavi) ve DSİ2 (kırmızı) havza sınırları 
HGK_6 ile DSİ 6 çakıştırılmış halde Şekil 19'da görünmektedir. Minimum ve maksimum yatay konum farkları sırasıly $0.008 \mathrm{~m}$ ve $2139.733 \mathrm{~m}$ 'dir. 12,301 ölçüyle yapılan hesap sonucunda DSİ6'nın ortalama yatay konum hatası $m_{l}=210.60 \mathrm{~m}$ olarak bulunmuştur.

DSİ havzalarının ağırlıklı ortalama yatay konum hatası, DSİ_2 ve DSİ6 havzalarının ortalama yatay konum hataları $\left(m_{l_{1}}=145.39 \mathrm{~m}\right.$ ve $\left.m_{l_{2}}=210.60 \mathrm{~m}\right)$ ve ölçü sayıları $\left(w_{1}=\right.$ 10,838 ve $\left.w_{2}=12,301\right)$ kullanılarak Bağıntı 3 ile $\bar{m}_{l}=180.06 \mathrm{~m}$ olarak hesaplanmıştır. Ancak, DSİ havza sınırlarının üretiminde kullanılan SYM çözünürlüğü hariç diğer verilerin ortalama yatay konum hatası tam olarak bilinmediği için Bağıntı 4'e göre eşik değer hesaplanamamıştır. Bununla birlikte, Bağıntı 5'e göre eşik değer, $M_{l_{2}}=2 \times 90=$ \pm 180 m'dir. Buna göre, DSİ havzalarının ağırlıklı ortalama yatay konum hatası, çok az da olsa eşik değerden büyüktür. Bu çalışmada türetilen havza sınırlarının ağırlıklı ortalama yatay konum doğruluğu ile DSİ havza sınırlarının ağırlıklı ortalama yatay konum doğruluğu karşılaştırıldı̆̆ında ise, bu çalışmada türetilen havza sınırlarının ağırlıklı ortalama yatay konum doğruluğunun $\left(\bar{m}_{l}=15.14 \mathrm{~m}\right)$, DSİ havza sınırlarının ağılıklı ortalama yatay konum doğruluğundan yaklaşık 12 kat daha yüksek olduğu görünmektedir.

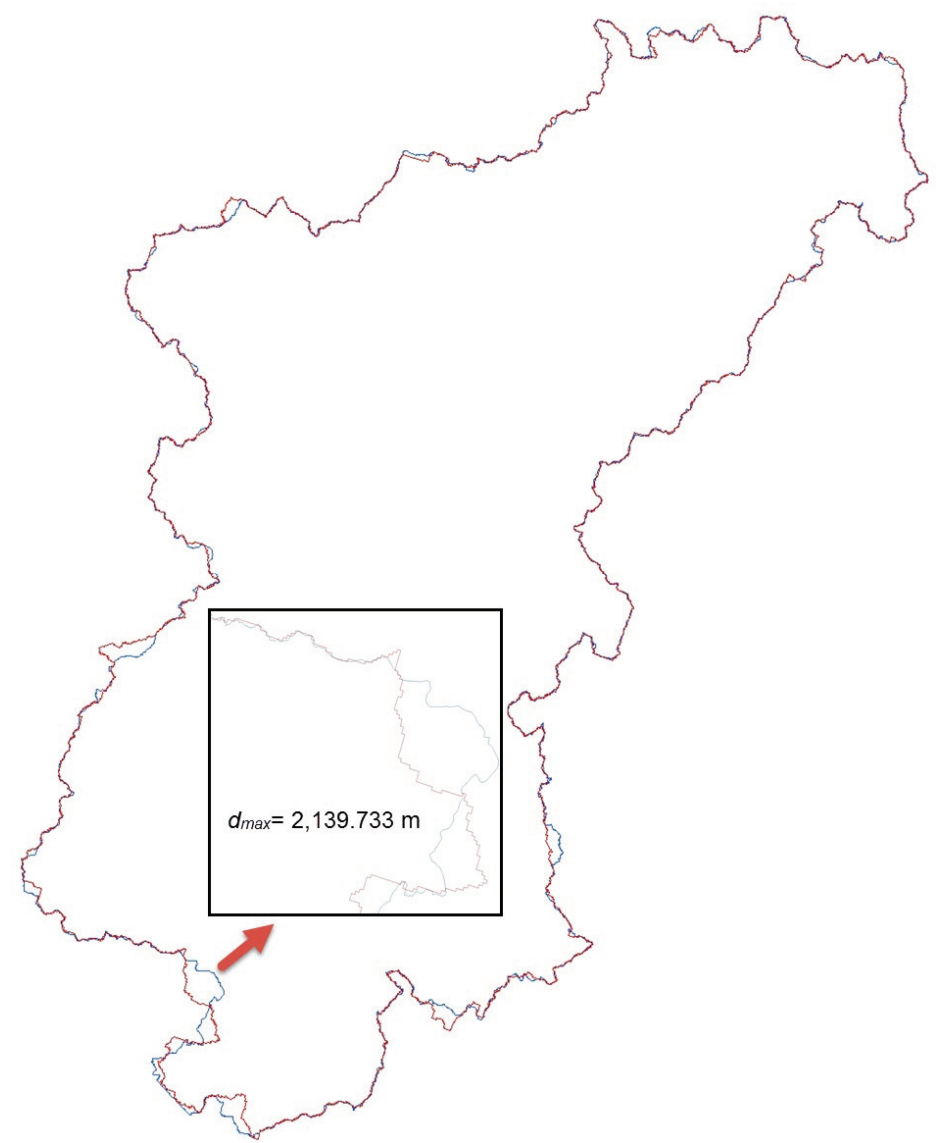

Şekil 19 - HGK_6 (mavi) ve DSİ6 (kırmızı) havza sinırları 


\section{SONUÇ VE ÖNERILER}

CBS'de yapılan analizlerin ve elde edilen sonuçların kalitesi, öncelikle verinin kalitesine bağlıdır. Veri ne kadar kaliteli ise elde edilen sonuçlar da o kadar kaliteli olacaktır. Bunun tersi de doğrudur. SYM üretiminde kullanılan yükseklik ve hidrografya verilerinde kalitatif ve kantitatif çok sayıda hata ile karşılaşılmıştır. Bu hataların büyük bir kısmı bu çalışma kapsaminda AutoLISP programlama dilinde yazılan iki program (tersdere.lsp ve kasislidere.lsp) yardımıyla otomatik olarak giderilmiştir. Geriye kalanlar ise CBS araçları yardımıyla yarı otomatik ve/veya manuel giderilmiştir. Bu çalışmada yapıldığı gibi, verilerdeki hataları gidermek için çeşitli araçlar geliştirilebilir ancak, esas hedef hatasız veri üretmek olmalıdır. Başka bir deyişle, hataları gidermek için değil, hatasız veri üretmek için araçlar geliştirilmelidir. Verimlilik ve veri kalitesi arasında en uygun dengeyi sağlayacak şekilde geliştirilecek araçlar sayesinde otomatik kontrollü üretim gerçekleştirilebilir. Geliştirilecek otomatik kontrol araçları veri üretim faaliyetinin bir miktar yavaşlamasına neden olabilir. Ancak, veriyi temizlemek için harcanacak zaman ve her şeye rağmen verinin bütünüyle temizlenememe olasılığg göz önüne alındığında, bunun anlamlı, faydalı, değerli ve gerekli olduğu anlaşılacaktır.

Yükseklik ve hidrografya verileriyle SYM üretimi bilinen ve yaygın olarak kullanılan bir yöntemdir. Ancak, üretilen SYM'in doğruluk analizi genellikle yapılmamaktadır. Oysaki SYM, hidrolojik analizlerin iki temel girdisinden biridir. SYM'in doğruluğu, hidrolojik analizlerin ve bu analizlerden elde edilecek ürünlerin doğruluğunu doğrudan etkiler. Bu çalışmada, üretilen SYM'in ağırlıklı karesel ortalama düşey konum hatası özgün bir yöntemle belirlenmiştir. Elde edilen sonuçlara göre, üretilen SYM'in ortalama düşey konum doğruluğu, SYM üretiminde kullanılan verilerin ortalama düşey konum doğruluğundan daha yüksektir ve ASPRS, NMAS ve NSSDA standartlarına göre kabul edilebilir niteliktedir. Bu sonuç, veri temizleme işleminin yeterli düzeyde yapıldığının ve üretilen SYM'in güvenle kullanılabileceğinin bir ispatıdır. Ayrıca, böyle yüksek doğruluklu bir SYM'den türetilecek drenaj ağlarının ve havzaların da yüksek doğruluklu olacağına dair bir güven ölçütüdür. SYM doğruluk analizinin ülkemizde bir standart haline getirilmesi büyük önem arz etmektedir. SYM doğruluk analizi, yönetmelik, teknik şartname vb. ile bir zorunluluk haline getirilmelidir. Yeterli doğrulukta olmayan SYM'lerin kullanılmasına ve bu SYM'lerle çeşitli ürünler elde edilmesine izin verilmemelidir.

Çalışma bölgesine ait SYM'in bir adımda tek parça halinde üretimi ideal olandır. Ancak, bu çalışmada kullanılan verilerin hacmi, SYM üretiminde kullanılan CBS aracının kapasitesinin çok üstünde olduğu için, pafta bazında 207 adet bindirmeli SYM üretilmiş ve sonra bunlar kaynaştırılmıştır. SYM bindirme mesafesi, yapılan bir dizi test sonucunda belirlenmiştir. Üretilen SYM'in yüksek doğruluklu olmasında bu test çalışmasının da önemli bir katkısı olmuştur.

Hidrolojik analiz için ikinci temel girdi olan hidrolojik ağın meydana getirilmesi son derece önemli bir aşamadır. Olabildiğince doğal nesnelerle ve arazi şekilleri dikkatlice incelenerek hidrolojik ağ meydana getirilmelidir. Gerekirse arazide kontrol bile yapılabilir. Bu çalışmada, Avlan Gölü bölgesinde hidrolojik ağda bir kopukluk olduğu ve bunun nedeninin de Avlan Gölü yakınındaki eyer biçimli bir boyun olduğu, gerek münhaniler üzerinde gerekse uydu görüntüleri üzerinde yapılan incelemeler sonucu, hiç şüpheye yer olmaksızın tespit edilmiştir. Böylece, aynı zamanda Avlan bölgesindeki çukur ve kapalı havza da tespit 
edilmiştir. DSİ tarafından yapılan daha önceki çalışmalarda bu boyun tespit edilemediği için DSİ drenaj ağlarında bu bölgede bir kopukluk yoktur ve bu kapalı havza tespit edilememiştir.

Akış birikinti eşik değeri, hidrolojik analiz sonucu elde edilecek drenaj ağını ve havza sınırlarını doğrudan etkileyen kullanıcı tanımlı ve önemli bir parametredir. BeST yaklaşımıyla, memba noktalarının birbirine bir hücre büyüklüğünden daha yakın olmayacağı drenaj ağını üretecek ilk akış birikinti değeri belirlenmektedir. Bu nedenle, BeST değeriyle elde edilen drenaj ağında paralel çizgiler ortaya çıkmamıştır. BeST değeri aslında akış birikinti eşik değerleri için de bir eşik değerdir. Başka bir deyişle, bir akış birikinti eşik değeri, BeST değerinden küçükse, o eşik değerle türetilecek drenaj ağının memba noktalarından bazılarının birbirlerine bir hücre büyüklüğü yakınlığında olabileceği veya tersi durumda (bir akış birikinti eşik değeri BeST değerinden büyükse) memba noktalarının birbirlerine bir hücre büyüklüğünde yakın olmayacağı önceden tespit edilebilir. BeST değeri, kullanılabilecek en küçük eşik değer olduğu için, BeST değeriyle elde edilen drenaj ağı, en fazla nesne sayısına sahip ve toplam uzunluğu en fazla drenaj ağı olacaktır.

$\mathrm{Bu}$ güne kadar yapılan benzer çalışmalar incelendiğinde, türetilen havza sınırlarının doğruluğuna ilişkin, ölçülere dayalı olarak ortaya konmuş bir bilgiye rastlanmamaktadır. $\mathrm{Bu}$ çalışmada, havza sınırlarının ortalama yatay konum doğruluğu özgün bir yöntemle belirlenmiştir. $\mathrm{Bu}$ amaç doğrultusunda AutoLISP programlama dilinde yazılan bir program (rmse.lsp) yardımıyla işlemler büyük ölçüde otomatik gerçekleştirilmiş̧ir. Bu çalışmada türetilen havza sınırlarının ağırlıklı karesel ortalama yatay konum hatasının, bu çalışmada kullanılan verilerin ortalama yatay konum hatasına ve SYM çözünürlüğüne bağlı olarak hesaplanan eşik değerin çok altında olduğu ve ayrıca ASPRS standartlarına göre kabul edilebilir nitelikte olduğu tespit edilmiş̧ir. Ayrıca, bu çalışmada türetilen havza sınırlarının ortalama yatay konum doğruluğunun, DSİ havza sınırlarının ortalama yatay konum doğruluğundan yaklaşık 12 kat daha yüksek olduğu tespit edilmiştir. Başka bir deyişle, bu çalışmada, yüksek doğruluklu bir SYM'den yüksek doğruluklu havza sınırları türetilmiştir.

\section{Semboller}

$\begin{array}{ll}\text { BeST } & \text { : Best Stream Threshold } \\ \text { CBS } & \text { : Coğrafi Bilgi Sistemleri } \\ \text { SYM } & \text { : Sayisal Yükseklik Modeli } \\ \text { PPA } & \text { : Profile Recognition and Polygon Breaking Algorithm } \\ \text { WFD } & : \text { Water Framework Directive } \\ \text { INSPIRE } & \text { : Infrastructure for Spatial Information in Europe } \\ \text { HGK } & \text { : Harita Genel Komutanlığ } \\ \text { GPS } & \text { : Global Positioning System } \\ \text { IMU } & : \text { Inertial Measurement Unit } \\ \text { ASPRS } & : \text { American Society for Photogrammetry and Remote Sensing } \\ \text { NMAS } & \text { : National Map Accuracy Standard }\end{array}$




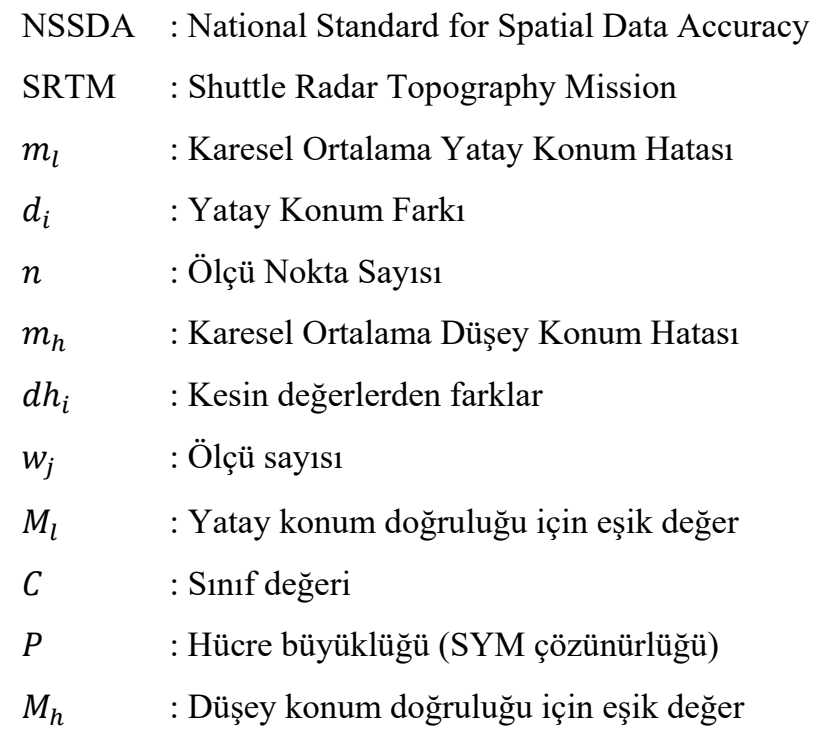

\section{Teşekkür}

Yazarlar, çalışmaya desteğinden dolayı TÜBİTAK'a (Proje No: 115Y411), Prof. Dr. Zekâi Şen'e ve makalenin gelişmesine katkıda bulunan hakemlere teşekkür eder.

\section{Kaynaklar}

[1] Güler, A., Sayısal Arazi Modellerinde İnterpolasyon Yöntemleri, Harita Dergisi, 85, 53-70, 1978.

[2] Hutchinson, M.F., A New Procedure for Gridding Elevation and Stream Data with Automatic Removal of Spurious Pits, Journal of Hydrology, 106, 211-232, 1989.

[3] Hengl, T., Evans, I.S., Mathematical and Digital Models of the Land Surface, Developments in Soil Science, 33, 31-63, 2009.

[4] Finsterwalder, R., Zur Bestimmung von Tal-und Kammlinien, Zeitschrift für Vermessung Wesen, 111 (5), 184-89, 1986.

[5] Gökgöz, T., Generalization of Contours Using Deviation Angles and Error Bands, The Cartographic Journal, 42 (2), 145-156, 2005.

[6] Li, Z.L., Zhu, Q., Gold, C., Digital Terrain Modeling: Principles and Methodology, New York: CRC Press, 2005.

[7] Chang, K.T., Introduction to Geographic Information Systems (3. Basım), New York: Mc Graw Hill, 2006. 
[8] O'Callaghan, J.F., Mark, D.M., The Extraction of Drainage Networks from Digital Elevation Data, Computer Vision, Graphics and Image Processing, 28 (3), 323-344, 1984.

[9] Mark, D.M., Automated Detection of Drainage Networks from Digital Elevation Models, Cartographica, 21 (2-3), 168-178, 1984.

[10] Jenson, S.K., Dominque, J.O., Extracting Topographic Structure from Digital Elevation Data for Geographic Information System Analysis, Photogrammetric Engineering and Remote Sensing, 54 (11), 1593-1600, 1988.

[11] Zhou, Q., Liu, X., Error Assessment of Grid-Based Flow Routing Algorithms Used in Hydrological Models, International Journal of Geographical Information Science, 16 (8), 819-842, 2002.

[12] Zhang, W., Fu, C., Yan, X., Automatic Watershed Delineation for a Complicated Terrain in the Heihe River Basin, Northwestern China, IEEE International Geoscience and Remote Sensing Symposium, 4, 2347-2350, 2005.

[13] Gökgöz, T., Uluğtekin, N., Başaraner, M., Gülgen, F., Doğru, A.Ö., Bilgi, S., Yücel, M.A., Çetinkaya, S., Selçuk, M., Uçar, D., Watershed Delineation from Grid DEMs in GIS: Effects of Drainage Lines and Resolution, 10th International Specialised Conference on Diffuse Pollution and Sustainable Basin Management, 18-22 Eylül, İstanbul, Türkiye, 2006.

[14] Fairfield, J., Leymarie, P., Drainage Networks from Grid Digital Elevation Models, Water Resources Research, 27 (5), 709-717, 1991.

[15] Tribe, A., Automated Recognition of Valley Lines and Drainage Networks from Grid Digital Elevation Models: a Review and a New Method, Journal of Hydrology, 139, 263-293, 1992.

[16] Costa-Cabral, M.C., Burges, S.J., Digital Elevation Model Networks (DEMON): a Model of Flow Over Hillslopes for Computation of Contributing and Dispersal Areas, Water Resources Research, 30 (6), 1681-1692, 1994.

[17] Tarboton, D.G., A New Method for the Determination of Flow Directions and Upslope Areas in Grid Digital Elevation Models, Water Resources Research, 33 (2), 309-319, 1997.

[18] Garbrecht, J., Martz, L.W., The Assignment of Drainage Over Flat Surfaces in Raster Digital Elevation Models, Journal of Hydrology, 193, 204-213, 1997.

[19] Martz, L.W., Garbrecht, J., The Treatment of Flat Areas and Depressions in Automated Drainage Analysis of Raster Digital Elevation Models, Hydrological Processes, 12, 843-855, 1998.

[20] Turcotte, R., Fortin, J.P., Rousseau, A.N., Massicotte, S., Villeneuve, J.P., Determination of the Drainage Structure of a Watershed Using a Digital Elevation Model and a Digital River and Lake Network, Journal of Hydrology, 240, 225-242, 2001. 
[21] Jones, R., Algorithms for Using a DEM for Mapping Catchment Areas of Stream Sediment Samples, Computers \& Geosciences, 28 (1), 1051-1060, 2002.

[22] Gülgen, F., Gökgöz, T., A New Algorithm for Extraction of Continuous Channel Networks without Problematic Parallels from Hydrologically Corrected DEMs, Boletim de Ciencias Geodesicas, 16 (1), 20-38, 2010.

[23] Olivera, F., Furnans, J., Maidment, D.R., Djokic, D., Ye, Z., ArcHydro: GIS for Water Resources, Editör: Maidment, D.R., Redlands: ESRI Press, 2002.

[24] Tang, G.A., A Research on the Accuracy of Digital Elevation Models, Beijing: Science Press, 2000.

[25] Heine, R.A., Lant, C.L., Sengupta, R.R., Development and Comparison of Approaches for Automated Mapping of Stream Channel Networks, Annals of the Association of American Geographers, 94 (3), 477-490, 2004.

[26] EU Water Framework Directive. "Directive 2000/60/EC of the European Parliament and of the Council of 23 October 2000 Establishing a Framework for Community Action in the Field of Water Policy". http://ec.europa.eu/environment/water/waterframework/index_en.html Son erişim tarihi:19 Mart 2017.

[27] Çölleşme ve Erozyonla Mücadele Genel Müdürlügü. “Su Politikası Alanında Topluluk Faaliyeti için Bir Çalışma Çerçevesi Oluşturan 23 Ekim 2000 Tarihli Avrupa Parlamentosu ve Konseyinin 2000/60/EC Sayılı Direktifi”. http://www.cem.gov.tr/erozyon/Files/faaliyetler/dis_iliskiler/Avrupa_Birligi/AB_Su_ Cerceve_Tur.pdf Son erişim tarihi: 19 Mart 2017.

[28] Coğrafi Bilgi Sistemleri Genel Müdürlüğü. "INSPIRE Yol Haritası". http://www.csb.gov.tr/gm/cbs/index.php?Sayfa=sayfa\&Tur=webmenu\&Id=36623. Son erişim tarihi: 19 Mart 2017.

[29] INSPIRE Thematic Working Group Hydrography. "D2.8.I.8 INSPIRE Data Specification on Hydrography - Guidelines"

http://inspire.ec.europa.eu/documents/Data_Specifications/INSPIRE_DataSpecificatio n_HY_v3.0.1.pdf Son erişim tarihi: 19 Mart 2017.

[30] Hengl, T., Finding the Right Pixel Size, Computers \& Geosciences, 32, 1283-1298, 2006.

[31] Weihau, Z., Montgomery, D., Digital Elevation Model Grid Size, Landscape Representation, and Hydrologic Simulations, Water Resources Research, 30 (4), 10191028, 1994.

[32] Erdoğan, M., Veri Türü, Kalitesi ve Üretim Yöntemine Göre Sayısal Yükseklik Modeli (SYM) Standartlarının Belirlenmesi, Doktora Tezi, İstanbul Teknik Üniversitesi, İstanbul, 2007.

[33] De Jager, A.L., Vogt, J.V., Development and Demonstration of a Structured Hydrological Feature Coding System for Europe, Hydrological Sciences Journal, 55 (5), 661-675, 2010. 
[34] Multinational Geospatial Co-Production Program Technical Reference Documentation (Inherent Report), Harita Genel Komutanlığı, Ankara, 2009.

[35] American Society for Photogrammetry and Remote Sensing (ASPRS). ASPRS Positional Accuracy Standards for Digital Geospatial Data. http://www.asprs.org/a/society/committees/standards/ASPRS_Positional_Accuracy_S tandards_Edition1_Version100_November2014.pdf Son erişim tarihi: 19 Mart 2017.

[36] United States National Map Accuracy Standards, Office of Management and Budget, Washington, D.C. https://nationalmap.gov/standards/pdf/NMAS647.PDF Son erişim tarihi: 19 Mart 2017.

[37] Federal Geographic Data Committee, FGDC-STD-007.3-1998, Geospatial Positioning Accuracy Standards, Part 3: National Standard for Spatial Data Accuracy (NSSDA), FGDC, c/o U.S. Geological Survey. https://www.fgdc.gov/standards/projects/FGDCstandards-projects/accuracy/part3/chapter3 Son erişim tarihi: 19 Mart 2017. 
